\title{
Nepheline Syenite and Phonolite as Alternative Potassium Sources for Maize
}

\author{
Thiago Assis Rodrigues Nogueira ${ }^{1,2, *} \mathbb{\infty}$, Bruno Gasparoti Miranda ${ }^{1,2}$, Arshad Jalal ${ }^{2} \mathbb{D}$, \\ Luís Gustavo Frediani Lessa ${ }^{3}$, Marcelo Carvalho Minhoto Teixeira Filho ${ }^{2} \mathbb{0}$, Nericlenes Chaves Marcante ${ }^{4}$, \\ Cassio Hamilton Abreu-Junior ${ }^{5}{ }^{\circledR}$, Arun Dilipkumar Jani ${ }^{6}{ }^{\circledR}$, Gian Franco Capra ${ }^{7} \mathbb{D}$, Adônis Moreira ${ }^{8}$ \\ and Éder de Souza Martins ${ }^{9}$ (i)
}

check for updates

Citation: Nogueira, T.A.R.; Miranda, B.G.; Jalal, A.; Lessa, L.G.F.; Filho,

M.C.M.T.; Marcante, N.C.;

Abreu-Junior, C.H.; Jani, A.D.; Capra, G.F.; Moreira, A.; et al. Nepheline Syenite and Phonolite as Alternative Potassium Sources for Maize. Agronomy 2021, 11, 1385. https:// doi.org/10.3390/agronomy11071385

Academic Editor: Tim Weaver

Received: 4 June 2021

Accepted: 6 July 2021

Published: 9 July 2021

Publisher's Note: MDPI stays neutral with regard to jurisdictional claims in published maps and institutional affiliations.

Copyright: (c) 2021 by the authors. Licensee MDPI, Basel, Switzerland. This article is an open access article distributed under the terms and conditions of the Creative Commons Attribution (CC BY) license (https:// creativecommons.org/licenses/by/ $4.0 /)$.
1 School of Agricultural and Veterinarian Sciences, São Paulo State University (UNESP), Jaboticabal 14884-900, Brazil; bruno-gasparoti.miranda@unesp.br

2 School of Engineering, São Paulo State University (UNESP), Ilha Solteira 15385-000, Brazil; arshad.jalal@unesp.br (A.J.); mcm.teixeira-filho@unesp.br (M.C.M.T.F.)

3 College of Agricultural Science, São Paulo State University (UNESP), Botucatu 18610-034, Brazil; gustavo.lessa@unesp.br

4 Mineragro Pesquisa e Desenvolvimento, Brasília 73020-406, Brazil; marcante@mineragroservicos.com

5 Center for Nuclear Energy in Agriculture (CENA), Universidade de São Paulo (USP),

Piracicaba 13416-000, Brazil; cahabreu@cena.usp.br

6 USDA-NRCS Ecological Sciences Division, Portland, OR 97232, USA; arun.jani@usda.gov

7 Dipartimento di Architettura, Design e Urbanistica, Università degli Studi di Sassari, Polo Bionaturalistico, Via Piandanna No. 4, 07100 Sassari, Italy; pedolnu@uniss.it

$8 \quad$ Embrapa Soja, Londrina 86085-981, Brazil; adonis.moreira@embrapa.br

9 Embrapa Cerrados, Planaltina 73310-970, Brazil; eder.martins@embrapa.br

* Correspondence: tar.nogueira@unesp.br; Tel.: +55-(18)-3743-1946

Abstract: Some silicate rocks are a rich source of potassium (K), with the possibility for use in agriculture. The present study aimed to evaluate the agronomic efficiency index (AEI) of nepheline syenite (NS) and phonolite (PN) rocks in comparison with potassium chloride $(\mathrm{KCl})$ as a $\mathrm{K}$ source in maize production. An experiment was conducted in a greenhouse in Ilha Solteira, São Paulo, Brazil. A maize hybrid was grown in $8 \mathrm{~L}$ pots filled with $6 \mathrm{~kg}$ of soil with a low $\mathrm{K}$ concentration and contrasting physical attributes (medium and sandy texture). A completely randomized design in a $3 \times 6$ factorial scheme was used, consisting of three $\mathrm{K}$ sources (NS, PN, and $\mathrm{KCl}$ ) and six rates $\left(0,50,100,150,200\right.$, and $\left.400 \mathrm{mg} \mathrm{kg}^{-1}\right)$ with four replications. All plants were harvested 45 days after emergence to evaluate biomass production, macronutrient $(\mathrm{N}, \mathrm{P}, \mathrm{K}, \mathrm{Ca}, \mathrm{Mg}$, and $\mathrm{S}$ ) concentration and uptake, stem diameter, and leaf chlorophyll index. After crop harvest, soil was collected for further chemical evaluation, which included organic matter $(\mathrm{OM}), \mathrm{pH}$, cation exchange capacity (CEC), $\mathrm{H}+\mathrm{Al}, \mathrm{Al}$, sum of bases (SB), base saturation (BS), $\mathrm{P}, \mathrm{K}, \mathrm{Ca}, \mathrm{Mg}$, and $\mathrm{S}$. In addition, AEI of NS and $\mathrm{PN}$ were also verified in relation to $\mathrm{KCl}$. The application of $\mathrm{NS}$ and $\mathrm{PN}$ had a similar effect on soil chemical attributes (MO, $\mathrm{pH}, \mathrm{SB}, \mathrm{CEC}$, and $\mathrm{BS}$ ) as well as on the concentrations of $\mathrm{K}, \mathrm{Ca}, \mathrm{Mg}$, and $\mathrm{S}$, in both soils. The increase in NS and PN rates provided linear growth of shoot dry matter. Leaf macronutrient concentrations were similar for NS and PN compared to $\mathrm{KCl}$. All three $\mathrm{K}$ sources (NS, $\mathrm{PN}$, and $\mathrm{KCl}$ ) increased $\mathrm{K}$ accumulation in maize plants. Maize treated with $\mathrm{KCl}$ had the largest AEI, followed by PN and NS. However, the results indicated similar AEI with both rocks as a K source for maize, especially with application of the highest $\mathrm{K}$ rates. This research demonstrated the efficiency of NS and PN as alternative K sources for maize.

Keywords: Zea mays L.; rock powder; igneous rock; agronomic efficiency index

\section{Introduction}

Brazilian agriculture has experienced great progress in recent years, stemming from technological innovations that are the result of extensive and widespread research efforts. 
One of the most important components in achieving a high yield has been the use of fertilizers that aim to correct soil chemical attributes and increase the productive potential of crops through the supply of nutrients for crop development [1,2].

Among these nutrients, potassium $(\mathrm{K})$ is generally applied through $\mathrm{K}$ fertilizers with potassium chloride $(\mathrm{KCl})$ being the most used source due to its high concentration $\left(60 \% \mathrm{~K}_{2} \mathrm{O}\right)[3,4]$. However, the accentuated use of this fertilizer can cause severe adverse environmental impacts, since about half the amount applied may be lost through leaching, resulting in the contamination of rivers and groundwater [2,5]. The risk of $\mathrm{K}$ losses by leaching may be even greater in sandy soils, since the soil colloidal fraction may not retain large K concentrations [6].

In addition, excessive application of $\mathrm{K}$ salts increases cell external osmotic pressure, which may hinder absorption of water by seeds and radicles [7] thereby causing a reduction in seed germination. Another cause for concern is that Brazilian agricultural production is highly dependent on the import of $\mathrm{K}$ fertilizer, which compromises Brazil's food security. National fertilizer production in 2018 was around 8.2 million tons and imports amounted to 27.4 million tons [8], of which 10.5 million tons were $\mathrm{KCl}$ [9].

Brazil is abundant in several silicate rocks, which can possibly be used as sources of $\mathrm{K}$ in a ground-up form [10]. These rocks weather very slowly in their aggregate form. However, when applied to soils rich in organic matter, high biological activity, and large edaphic faunal populations, these rock minerals may break down relatively fast with nutrients such as K, making plants more available [11].

The use of these silicate agrominerals (soil remineralizers) is intended to reduce the dependence on the use of imported fertilizers [12,13]. In recent years, this practice has been investigated for its agronomic potential, especially in the supply of $\mathrm{K}$ in several regions of Brazil $[12,14,15]$ and the results have demonstrated the benefits of using rocks as sources of nutrients, leading to a good agronomic efficiency index (AEI) for crops [11,12,16,17].

Several studies were conducted with these materials as a source of $\mathrm{K}$ in the cultivation of maize (Zea mays L.) with promising results [18-21]. Maize is one of the most widely cultivated cereals globally, and $\mathrm{K}$ is the second most required nutrient [22]. Therefore, $\mathrm{K}$ fertilization is essential to produce acceptable yields.

Igneous rocks like nepheline syenite and phonolite contain considerable amounts of $\mathrm{K}_{2} \mathrm{O}$, which can be considered an alternative source of $\mathrm{K}$ in fertilizer markets. However, there are few studies evaluating the potential use of these two K sources in agricultural soils. Thus, the objective of this study was to evaluate the agronomic efficiency of nepheline syenite and phonolite in comparison to $\mathrm{KCl}$ as sources of $\mathrm{K}$ for maize on two soils with different chemical and physical attributes.

\section{Materials and Methods}

\subsection{Pot Experiment}

The experiment was conducted under greenhouse conditions at the School of Engineering of Sao Paulo State University (UNESP), Ilha Solteira, State of São Paulo, Brazil. Pots with $8 \mathrm{~L}$ soil capacity were used and filled with a Typic Quartzipsamment (TQ) and Rhodic Hapludox (RH) [23] collected in the 0 to $20 \mathrm{~cm}$ deep layer in the municipality of Selvíria, State of Mato Grosso do Sul, Brazil. The chemical and physical attributes of these soils are described in Table 1.

Lime was applied as $\mathrm{CaCO}_{3}$ and $\mathrm{MgCO}_{3} 30$ days before planting to maintain the Ca:Mg ratio of 3:1, thereby increasing base saturation up to $70 \%$ [24]. In the same period, sources of $\mathrm{K}$ (nepheline syenite: total phosphorus $\left(\mathrm{P}_{2} \mathrm{O}_{5}\right)<1 \%$ and $\mathrm{K}_{2} \mathrm{O}=8.0 \%$; phonolite: total phosphorus $\left(\mathrm{P}_{2} \mathrm{O}_{5}\right)<1 \%$ and $\mathrm{K}_{2} \mathrm{O}=9.1 \%$; and potassium chloride $\left.(\mathrm{KCl})=60 \% \mathrm{~K}_{2} \mathrm{O}\right)$ were applied. Nepheline syenite and phonolite are used as finely ground soil remineralizers (granulometry $<0.3 \mathrm{~mm}$ ) and were obtained in Lavrinhas-SP and Poços de Caldas-MG, Brazil, respectively. Subsequently, the soil samples were homogenized, packed in plastic bags, and incubated for 30 days with moisture concentration maintained at $60 \%$ of the 
water holding capacity. After the period of incubation, soil samples were collected from each pot to determine the $\mathrm{pH}$.

The experiment was set up using a completely randomized design with four replications. The treatments were arranged in a $3 \times 6$ factorial scheme, consisting of three $\mathrm{K}$ sources (nepheline syenite, phonolite, and $\mathrm{KCl})$ which were applied at six rates $(0,50,100$, 150,200 , and $400 \mathrm{mg} \mathrm{kg}^{-1}$ ). The pots received $100 \mathrm{mg} \mathrm{kg}^{-1}$ of $\mathrm{N}$ as ammonium sulfate (AS, $20 \% \mathrm{~N}$ ) and $200 \mathrm{mg} \mathrm{kg}^{-1}$ of $\mathrm{P}$ via monoammonium phosphate (MAP, $52 \%$ of $\mathrm{P}_{2} \mathrm{O}_{5}$ ) as recommended by Malavolta [25] before planting.

Table 1. Chemical and physical attributes ${ }^{1}$ of soil samples used in the experiment (Mean \pm standard deviation; $n=3$ ).

\begin{tabular}{|c|c|c|c|}
\hline \multirow{2}{*}{ Attributes } & \multirow{2}{*}{ Units } & \multicolumn{2}{|c|}{ Soils $^{2}$} \\
\hline & & TQ & RH \\
\hline $\mathrm{pH}\left(\mathrm{CaCl}_{2}\right)$ & - & $5.1 \pm 0.15$ & $4.3 \pm 0.06$ \\
\hline SOM & $\mathrm{g} \mathrm{dm}^{-3}$ & $13 \pm 0.58$ & $21 \pm 2.31$ \\
\hline $\mathrm{P}$ & $\mathrm{mg} \mathrm{dm}{ }^{-3}$ & $2 \pm 0.58$ & $7 \pm 0.58$ \\
\hline $\mathrm{K}^{+}$ & $\mathrm{mmol}_{\mathrm{C}} \mathrm{dm}^{-3}$ & $0.3 \pm 0.06$ & $0.7 \pm 0.15$ \\
\hline $\mathrm{Ca}^{2+}$ & $\mathrm{mmol}_{\mathrm{c}} \mathrm{dm}^{-3}$ & $7 \pm 0.00$ & $9 \pm 2.65$ \\
\hline $\mathrm{Mg}^{2+}$ & $\mathrm{mmol}_{\mathrm{C}} \mathrm{dm}^{-3}$ & $7 \pm 0.58$ & $6 \pm 1.15$ \\
\hline $\mathrm{S}-\mathrm{SO}_{4}$ & $\mathrm{mg} \mathrm{dm}^{-3}$ & $4 \pm 1.73$ & $6 \pm 0.58$ \\
\hline $\mathrm{Al}^{3+}$ & $\mathrm{mmol}_{\mathrm{C}} \mathrm{dm}^{-3}$ & $0.33 \pm 0.47$ & $9 \pm 4.62$ \\
\hline $\mathrm{H}+\mathrm{Al}$ & $\mathrm{mmol}_{\mathrm{C}} \mathrm{dm}^{-3}$ & $15 \pm 0.58$ & $45 \pm 5.77$ \\
\hline SB & $\mathrm{mmol}_{\mathrm{C}} \mathrm{dm}^{-3}$ & $14.0 \pm 0.61$ & $16.0 \pm 3.92$ \\
\hline BS & $\%$ & $48 \pm 2.00$ & $26 \pm 7.23$ \\
\hline CEC & $\mathrm{mmol}_{\mathrm{C}} \mathrm{dm}^{-3}$ & $29.3 \pm 0.52$ & $61.3 \pm 1.93$ \\
\hline B & $m g \mathrm{dm}^{-3}$ & $0.05 \pm 0.02$ & $0.20 \pm 0.02$ \\
\hline $\mathrm{Cu}$ (DTPA) & $m g \mathrm{dm}^{-3}$ & $0.7 \pm 0.06$ & $2.5 \pm 0.10$ \\
\hline $\mathrm{Fe}$ (DTPA) & $m g \mathrm{dm}^{-3}$ & $17 \pm 0.00$ & $24 \pm 2.52$ \\
\hline Mn (DTPA) & $\mathrm{mg} \mathrm{dm}^{-3}$ & $5.4 \pm 0.31$ & $30.0 \pm 3.01$ \\
\hline Zn (DTPA) & $m g \mathrm{dm}^{-3}$ & $0.2 \pm 0.06$ & $0.7 \pm 0.06$ \\
\hline Sand $(>0.002$ and $<0.05 \mathrm{~mm})$ & $\mathrm{g} \mathrm{kg}^{-1}$ & $869 \pm 2.52$ & $544 \pm 4.51$ \\
\hline Silt $(>0.002$ and $<0.05 \mathrm{~mm})$ & $\mathrm{g} \mathrm{kg}^{-1}$ & $33 \pm 6.03$ & $116 \pm 3.61$ \\
\hline Clay $(<0.002 \mathrm{~mm})$ & $\mathrm{g} \mathrm{kg}^{-1}$ & $96 \pm 3.51$ & $340 \pm 4.36$ \\
\hline
\end{tabular}

${ }^{1}$ Analyses performed in accordance with official procedures [26,27]. ${ }^{2}$ Values on an air-dried basis. TQ = Typic Quartzipsamment. $\mathrm{RH}=$ Rhodic Hapludox. $\mathrm{SOM}=$ soil organic matter; $\mathrm{CEC}=$ cation-exchange capacity; $\mathrm{SB}=$ sum of bases; $\mathrm{BS}=$ base saturation.

Six seeds of maize hybrid (DOW 2B $710 \mathrm{PW}^{\circledR}$ ) were sown per pot and after nine days of seedling emergence (DSE), thinning was performed, leaving two plants per pot. A solution containing micronutrients $\left(1.0 \mathrm{mg} \mathrm{kg}^{-1}\right.$ of B as boric acid, $2.0 \mathrm{mg} \mathrm{kg}^{-1}$ of $\mathrm{Cu}$ as copper sulphate, $5.0 \mathrm{mg} \mathrm{kg}^{-1}$ of $\mathrm{Zn}$ as zinc sulphate and $3.0 \mathrm{mg} \mathrm{kg}^{-1}$ of Mn as manganese sulphate) was applied 10 DSE. A cover fertilization was performed by applying $100 \mathrm{mg} \mathrm{kg}^{-1}$ of $\mathrm{N}$ via ammonium sulfate. These applications were made in all treatments.

\subsection{Leaf Chlorophyll Index, Plant Height, and Stem Diameter}

Leaf chlorophyll index (LCI) was evaluated in the middle third fully expended leaves of two plants per pot at 45 DSE, using portable ClorofiLOG equipment (model CFL 1030, Falker). Plant height $(\mathrm{cm})$ and stem diameter $(\mathrm{mm})$ were obtained at $10 \mathrm{~cm}$ from ground level.

\subsection{Chemical Analysis}

\subsubsection{Plant Analysis}

Shoots were cut close to the ground 45 days after the emergence of maize $(\mathrm{BBCH}$ growth stage 3: stem elongation), washed in tap water, packed in paper bags, and placed in an air-forced oven at $60^{\circ} \mathrm{C}$ for $72 \mathrm{~h}$. After drying, the material of each treatment was 
weighed to obtain plant dry matter (DM) and then ground in a Wiley mill to determine concentration of $\mathrm{N}, \mathrm{P}, \mathrm{K}, \mathrm{Ca}, \mathrm{Mg}$, and S [28]. The concentration of $\mathrm{N}$ was determined by steam distillation in the sulfuric digestion extract. The concentrations of $\mathrm{K}, \mathrm{Ca}$, and $\mathrm{Mg}$ were determined by atomic absorption spectrophotometry (model: Perkin-Elmer, AAS-700, Norwalk, CT, USA), P by colorimetry, and S by turbidimetry. The accumulation of K (mg per plant) was calculated based on the shoot $\mathrm{K}$ concentration $\left(\mathrm{g} \mathrm{kg}^{-1}\right)$ and shoot dry matter (g per plant) of each treatment.

\subsubsection{Soil Analysis}

After harvesting plants, soil samples were collected to assess soil chemical attributes according to the methods described by Raij et al. [26] The soil $\mathrm{pH}$ values were determined potentiometrically in air-dried thin soil (ADTS) suspensions in a $0.01 \mathrm{~mol} \mathrm{~L}^{-1} \mathrm{CaCl}_{2}$ solution in a 1:2.5 soil-solution ratio. The organic matter was determined after oxidation with $\mathrm{K}_{2} \mathrm{Cr}_{2} \mathrm{O}_{7}$ in the presence of $\mathrm{H}_{2} \mathrm{SO}_{4}$ and titration of excess dichromate with $0.4 \mathrm{~mol} \mathrm{~L}^{-1}$ of $\mathrm{Fe}\left(\mathrm{NH}_{4}\right)_{2}\left(\mathrm{SO}_{4}\right)_{2} \cdot 6 \mathrm{H}_{2} \mathrm{O}$. Exchangeable aluminum $\left(\mathrm{Al}^{+3}\right)$ was extracted with $1 \mathrm{~mol} \mathrm{~L}^{-1}$ and then titrated with $0.025 \mathrm{~mol} \mathrm{~L}^{-1}$ of $\mathrm{NaOH}$. Exchangeable calcium $\left(\mathrm{Ca}^{+2}\right)$ and magnesium $\left(\mathrm{Mg}^{+2}\right)$ were extracted with ion exchange resin and quantified by atomic absorption spectrophotometry (AAS). Exchangeable potassium $\left(\mathrm{K}^{+}\right)$and phosphorus $(\mathrm{P})$ were also extracted by resin, $\mathrm{K}^{+}$being determined by flame photometry and $\mathrm{P}$ by colorimetry. Potential acidity $\left(\mathrm{H}+\mathrm{Al}^{+3}\right)$ was estimated by a $\mathrm{pH}$ SMP method. Sulfur was extracted by $0.01 \mathrm{~mol} \mathrm{~L}^{-1}$ solution of $\mathrm{Ca}\left(\mathrm{H}_{2} \mathrm{PO}_{4}\right)_{2}$ and subsequent measurement of turbidity formed by the precipitation of sulfate by barium chloride in colorimetry. These results were used to calculate the cation exchange capacity (CEC) at $\mathrm{pH} 7.0$, sum of bases (SB), and base saturation (BS\%).

\subsection{Agronomic Efficiency Index}

The agronomic efficiency index (AEI) of K sources was calculated according to the equation described by Goedert et al. [29]:

$$
\mathrm{AEI}(\%)=\frac{\text { SDM ASP }- \text { SDM CT }}{\text { SDM SAF }- \text { SDM CT }} \times 100
$$

where SDM ASP = shoot dry matter of alternative source of potassium, SDM CT = shoot dry matter of control treatment, and SDM SAF = shoot dry matter with standard applied fertilizer.

\subsection{Statistical Analysis}

The results were subjected to a normal data distribution test and then to the analysis of variance (ANOVA), F test, and subsequent polynomial regression studies for significant interactions and/or effect of $\mathrm{K}$ rates between variables evaluated in the soil and plants [30].

\section{Results and Discussion}

The $\mathrm{pH}$ values were changed after the period of 30 days of incubation of limestone and $\mathrm{K}$ sources in soils (Table 2). The $\mathrm{pH}$ values prior to incubation were 5.1 and 4.3 for Typic Quartzipsamment (TQ) and Rhodic Hapludox (RH), respectively (Table 1), and after the incubation period increased to 5.5 and 5.6 (Table 2). Thus, it was noted that there was an effective correction of the soil $\mathrm{pH}$ within the 5.5 to 6.5 range as indicated, suitable for the cultivation of maize [31]. After maize cultivation, there were interactions between $\mathrm{K}$ sources and rates for the values of $\mathrm{H}+\mathrm{Al}, \mathrm{Al}^{3+}$, and CEC in TQ and $\mathrm{pH}$ in the $\mathrm{RH}$ (Table 3). The $\mathrm{pH}, \mathrm{H}+\mathrm{Al}$, and $\mathrm{Al}^{3+}$ differed between the $\mathrm{K}$ sources in $\mathrm{TQ}$, while in the $\mathrm{RH}$ soil, a difference was noted only for the $\mathrm{pH}$ and $\mathrm{H}+\mathrm{Al}$, which demonstrates a similarity between nepheline syenite and phonolite sources for the chemical attributes in two investigated pedotypes. 
Table 2. $\mathrm{pH}$ values ${ }_{(\mathrm{CaCl} 2)}$ obtained after 30 days of incubation and before sowing the maize crop according to the treatments studied.

\begin{tabular}{lcc}
\hline \multirow{2}{*}{ Treatments } & Typic Quartzipsamment & Rhodic Hapludox \\
\cline { 2 - 3 } & Sandy Texture & Medium Texture \\
\hline Source $(\mathrm{F})$ & 5.5 & \\
Nepheline syenite & 5.4 & 5.5 \\
Phonolite & 5.5 & 5.4 \\
KCl & $1.52^{\mathrm{NS}}$ & 5.5 \\
F-test & & $0.26^{\mathrm{NS}}$ \\
K rates $(\mathrm{DK})$ & 5.5 & \\
$0\left(\mathrm{mg} \mathrm{kg}^{-1}\right)$ & 5.5 & 5.6 \\
$50\left(\mathrm{mg} \mathrm{kg}^{-1}\right)$ & 5.5 & 5.5 \\
$100\left(\mathrm{mg} \mathrm{kg}^{-1}\right)$ & 5.5 & 5.6 \\
$150\left(\mathrm{mg} \mathrm{kg}^{-1}\right)$ & 5.4 & 5.6 \\
$200\left(\mathrm{mg} \mathrm{kg}^{-1}\right)$ & 5.4 & 5.5 \\
$400\left(\mathrm{mg} \mathrm{kg}^{-1}\right)$ & $5.25^{* *}$ & 5.5 \\
F-test & $2.06^{*}$ & $1.87^{\mathrm{NS}}$ \\
F-test $(\mathrm{P}) \times(\mathrm{DK})$ & 5.5 & $1.42^{\mathrm{NS}}$ \\
Means & 1.3 & 5.6 \\
CV $(\%)$ & & 1.6 \\
\hline
\end{tabular}

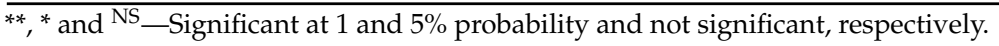

Regarding the $\mathrm{pH}$ values, there was no difference between nepheline syenite and phonolite with both of the soils being higher than with application of $\mathrm{KCl}$. This fact may be related to a greater absorption of $\mathrm{K}$ and other exchangeable bases ( $\mathrm{Ca}$ and $\mathrm{Mg}$ ) with greater release of $\mathrm{H}^{+}$ions by plants to the soil solution [12]. There were differences between two soils with $\mathrm{KCl}$ application. The effect was only detected on $\mathrm{pH}$ in the TQ and may have been due to higher concentrations of $\mathrm{Al}^{3+}\left(1.9 \mathrm{mmol}_{\mathrm{c}} \mathrm{dm}^{-3}\right)$, while the absence of an effect in the $\mathrm{RH}$ might be explained by the $\mathrm{pH}$ values being above 5.2 (Table 3), with $\mathrm{Al}^{3+}$ precipitated in soil [32]. The rates of $\mathrm{K}$ had a significant effect on $\mathrm{pH}, \mathrm{H}+\mathrm{Al}_{1} \mathrm{Al}^{3+}$ and CEC (Table 4). The increasing rates in phonolite increased $\mathrm{pH}$ values with a variation of 4.9 to 5.3 in the TQ and from 5.3 to 5.6 in the RH (Table 4). These values are classified as high to medium acidity for TQ and average to low acidity in $\mathrm{RH}$ [33]. The rates of $\mathrm{KCl}$ were effective only in $\mathrm{TQ}$, with a linear increase for $\mathrm{H}+\mathrm{Al}$ and $\mathrm{CEC}$ and a quadratic effect for $\mathrm{Al}^{3+}$ with a maximum point in the rates of 260 and $290 \mathrm{mg} \mathrm{kg}^{-1}$ respectively (Table 5).

There was an interaction between sources and rates of $\mathrm{K}$ for the concentrations of $\mathrm{K}$, $\mathrm{Ca}, \mathrm{Mg}$, and $\mathrm{S}$ in the $\mathrm{TQ}$, whereas it was with $\mathrm{K}$ and $\mathrm{S}$ in $\mathrm{RH}$ (Table 6). With the exception of $\mathrm{P}$ and $\mathrm{Mg}$ concentrations in the $\mathrm{TQ}$ and $\mathrm{Mg}$ concentrations in the $\mathrm{RH}$, there was variations in macronutrient concentrations for the investigated $\mathrm{K}$ sources. 


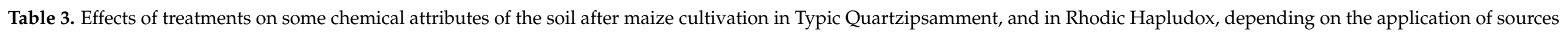
and rates of $\mathrm{K}$.

\begin{tabular}{|c|c|c|c|c|c|c|c|c|c|c|c|c|c|c|}
\hline \multirow{2}{*}{ Treatments } & \multicolumn{7}{|c|}{ Typic Quartzipsamment } & \multicolumn{7}{|c|}{ Rhodic Hapludox } \\
\hline & OM & $\mathrm{pH}$ & $\mathrm{H}+\mathrm{Al}$ & Al & SB & CEC & BS & OM & $\mathrm{pH}$ & $\mathrm{H}+\mathrm{Al}$ & Al & SB & CEC & BS \\
\hline Source (F) & $\mathrm{g} \mathrm{dm}^{-3}$ & $\mathrm{CaCl}_{2}$ & \multicolumn{4}{|c|}{$\mathrm{mmol}_{\mathrm{c}} \mathrm{dm}^{-3}$} & $\%$ & $\mathrm{~g} \mathrm{dm}^{-3}$ & $\mathrm{CaCl}_{2}$ & \multicolumn{4}{|c|}{$\mathrm{mmol}_{\mathrm{c}} \mathrm{dm}^{-3}$} & $\%$ \\
\hline Nepheline syenite & 11.8 & $4.9 \mathrm{a}^{2}$ & 18.7 a & $1.0 \mathrm{~b}$ & $17.3 \mathrm{ab}$ & 36.1 & $48.1 \mathrm{ab}$ & $17.6 \mathrm{~b}$ & $5.3 a^{2}$ & $27.2 \mathrm{~b}$ & 0 & 51.5 & 78.7 & $65.4 \mathrm{a}$ \\
\hline Phonolite & 11.8 & $5.0 \mathrm{a}$ & $17.0 \mathrm{~b}$ & $0.2 \mathrm{c}$ & 17.6 a & 35.1 & $50.6 \mathrm{a}$ & $18.2 \mathrm{a}$ & $5.3 \mathrm{a}$ & $27.7 \mathrm{~b}$ & 0 & 52.6 & 80.3 & $65.4 \mathrm{a}$ \\
\hline $\mathrm{KCl}$ & 11.7 & $4.6 \mathrm{~b}$ & $19.1 \mathrm{a}$ & $1.9 \mathrm{a}$ & $15.9 \mathrm{~b}$ & 34.6 & $45.2 \mathrm{~b}$ & $18.6 \mathrm{~b}$ & $5.2 \mathrm{~b}$ & $30.3 \mathrm{a}$ & 0 & 50.1 & 80.4 & $62.1 \mathrm{~b}$ \\
\hline F-test & $0.11^{\mathrm{NS}}$ & $26.40^{* *}$ & $5.59^{* *}$ & $21.5^{* *}$ & $3.97 *$ & $1.47^{\mathrm{NS}}$ & $8.33^{* *}$ & $10.99^{* *}$ & $10.45^{* *}$ & $6.47^{* *}$ & $0.00^{\mathrm{NS}}$ & $1.60^{\mathrm{NS}}$ & $0.67^{\mathrm{NS}}$ & $7.36^{* *}$ \\
\hline $\mathrm{K}$ rates (DK) & & & & & & & & & & & & & & \\
\hline $0\left(\mathrm{mg} \mathrm{kg}^{-1}\right)$ & 11.5 & 4.8 & 18.4 & 1.0 & 15.0 & 33.9 & 45.1 & 18.0 & 5.3 & 28.0 & 0 & 52.7 & 80.7 & 65.4 \\
\hline $50\left(\mathrm{mg} \mathrm{kg}^{-1}\right)$ & 11.9 & 4.8 & 18.6 & 0.9 & 15.7 & 34.3 & 45.5 & 18.0 & 5.2 & 29.0 & 0 & 50.5 & 79.5 & 63.5 \\
\hline $100\left(\mathrm{mg} \mathrm{kg}^{-1}\right)$ & 11.8 & 4.8 & 18.2 & 1.3 & 16.6 & 34.9 & 47.6 & 18.1 & 5.3 & 28.5 & 0 & 49.2 & 77.7 & 63.2 \\
\hline $150\left(\mathrm{mg} \mathrm{kg}^{-1}\right)$ & 12.0 & 4.9 & 17.6 & 0.9 & 17.5 & 35.2 & 49.5 & 18.0 & 5.3 & 27.0 & 0 & 51.6 & 78.6 & 65.6 \\
\hline $200\left(\mathrm{mg} \mathrm{kg}^{-1}\right)$ & 11.7 & 4.8 & 18.0 & 1.2 & 18.0 & 36.8 & 51.0 & 18.2 & 5.3 & 29.4 & 0 & 49.2 & 79.1 & 62.8 \\
\hline $400\left(\mathrm{mg} \mathrm{kg}^{-1}\right)$ & 11.9 & 4.9 & 19.0 & 0.9 & 18.8 & 37.0 & 49.0 & 18.5 & 5.3 & 28.7 & 0 & 49.76 & 83.2 & 65.3 \\
\hline F-test & $0.73 \mathrm{NS}$ & $0.70^{\mathrm{NS}}$ & $0.52 \mathrm{NS}$ & $0.56^{\mathrm{NS}}$ & $5.25 * *$ & $2.65^{*}$ & $3.09 *$ & $1.03 \mathrm{NS}$ & $0.75^{\mathrm{NS}}$ & $0.86^{\mathrm{NS}}$ & $0.00^{\mathrm{NS}}$ & $1.96 \mathrm{NS}$ & $1.41^{\mathrm{NS}}$ & $1.65^{\mathrm{NS}}$ \\
\hline$F$-test $(\mathrm{F}) \times(\mathrm{DK})$ & $7.03^{* *}$ & $1.51^{\mathrm{NS}}$ & $2.86^{* *}$ & $2.09 *$ & $3.28^{* *}$ & $4.92 * *$ & $1.47^{\mathrm{NS}}$ & $1.42^{\mathrm{NS}}$ & $4.66^{* *}$ & $1.72^{\mathrm{NS}}$ & $0.00^{N S}$ & 1.60 NS & $0.84^{\mathrm{NS}}$ & 2.48 * \\
\hline Means & 11.8 & 4.8 & 18.3 & 1.0 & 16.9 & 35.3 & 48.0 & 18.1 & 5.3 & 28.4 & 0 & 51.4 & 79.8 & 64.3 \\
\hline CV $(\%)$ & 5.0 & 4.6 & 12.4 & 80.4 & 12.7 & 8.3 & 9.5 & 4.1 & 2.1 & 11.2 & 0 & 9.4 & 7.0 & 5.2 \\
\hline
\end{tabular}

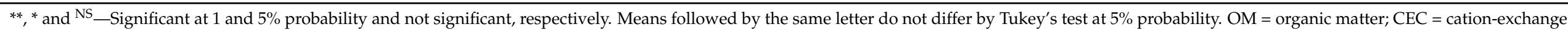
capacity; $\mathrm{SB}=$ sum of bases; $\mathrm{BS}$ = base saturation. 
Table 4. Chemical attributes of a Typic Quartzipsamment and a Rhodic Hapludox after maize cultivation, depending on the rates and sources of K.

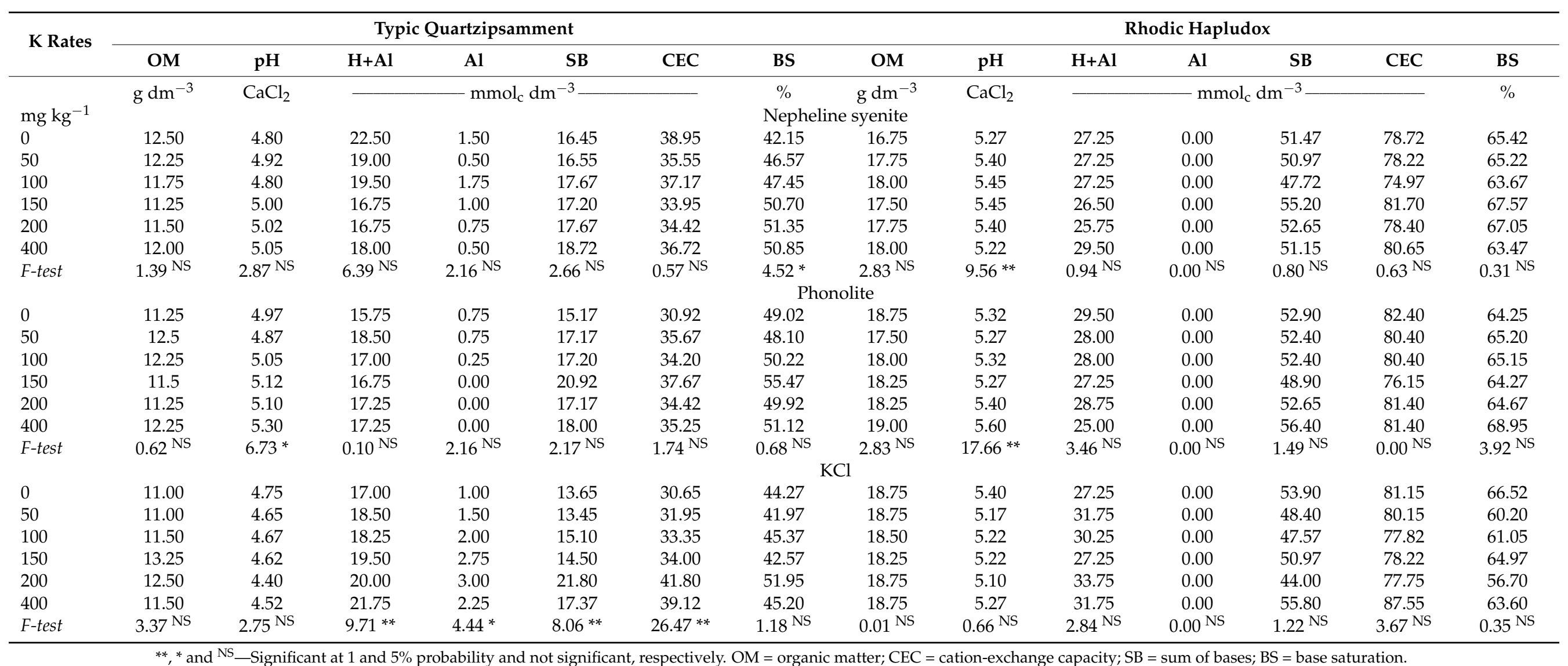


Table 5. Determination coefficients $\left(\mathrm{R}^{2}\right)$ and regression equations that best fit the relationships between the chemical attributes of soils after maize cultivation as a function of potassium sources.

\begin{tabular}{|c|c|c|c|c|}
\hline \multirow{2}{*}{$\begin{array}{c}\text { Variable } \\
\text { (y) }\end{array}$} & \multicolumn{2}{|c|}{ Typic Quartzipsamment } & \multicolumn{2}{|l|}{ Rhodic Hapludox } \\
\hline & Equation & $\mathbf{R}^{2}$ & Equation & $\mathbf{R}^{2}$ \\
\hline & & Nepheli & syenite & \\
\hline $\mathrm{OM}$ & $y=11.87$ & $0.11 \mathrm{NS}$ & $y=17.62$ & $0.36^{\mathrm{NS}}$ \\
\hline $\mathrm{pH}$ & $\mathrm{y}=4.93$ & $0.60^{\mathrm{NS}}$ & $y=5.30+0.001 x-0.000004 x^{2}$ & $0.89^{* *}$ \\
\hline $\mathrm{H}+\mathrm{Al}$ & $y=18.75$ & $0.35^{\mathrm{NS}}$ & $\mathrm{y}=27.25$ & $0.30^{\mathrm{NS}}$ \\
\hline $\mathrm{Al}$ & $y=1.00$ & $0.29 \mathrm{NS}$ & $y=0.00$ & $0.27 \mathrm{NS}$ \\
\hline SB & $y=17.97$ & $0.87^{\mathrm{NS}}$ & $y=51.52$ & $0.01^{\mathrm{NS}}$ \\
\hline CEC & $y=36.12$ & $0.07^{\mathrm{NS}}$ & $y=78.77$ & $0.18^{\mathrm{NS}}$ \\
\hline \multirow[t]{2}{*}{ BS } & $y=42.50+0.069 x-0.0001 x^{2}$ & $0.97 *$ & $y=65.40$ & $0.06^{\mathrm{NS}}$ \\
\hline & & Pho & olite & \\
\hline $\mathrm{OM}$ & $y=11.83$ & $0.03 \mathrm{NS}$ & $y=18.29$ & $0.28^{\mathrm{NS}}$ \\
\hline $\mathrm{pH}$ & $y=4.93+0.0009 x$ & $0.84 *$ & $y=5.25+0.0007 x$ & $0.79^{* *}$ \\
\hline $\mathrm{H}+\mathrm{Al}$ & $y=17.08$ & $0.03^{N S}$ & $y=27.75$ & $0.73^{\mathrm{NS}}$ \\
\hline $\mathrm{Al}$ & $y=0.29$ & $0.59^{\mathrm{NS}}$ & $y=0.00$ & $0.00^{\mathrm{NS}}$ \\
\hline SB & $y=17.60$ & $0.14^{\mathrm{NS}}$ & $y=52.60$ & $0.31^{\mathrm{NS}}$ \\
\hline CEC & $y=34.69$ & $0.15^{\mathrm{NS}}$ & $y=80.35$ & $0.00^{\mathrm{NS}}$ \\
\hline BS & $y=50.64$ & $0.10^{\mathrm{NS}}$ & $\mathrm{y}=65.41$ & $0.70 \mathrm{NS}$ \\
\hline $\mathrm{OM}$ & $y=11.79$ & $0.07^{\mathrm{NS}}$ & $y=18.65$ & $0.00^{\mathrm{NS}}$ \\
\hline $\mathrm{pH}$ & $y=4.60$ & $0.46^{\mathrm{NS}}$ & $y=5.23$ & $0.04^{\mathrm{NS}}$ \\
\hline $\mathrm{H}+\mathrm{Al}$ & $y=17.47+0.011 x$ & $0.94^{* *}$ & $y=30.33$ & $0.20^{\mathrm{NS}}$ \\
\hline $\mathrm{Al}$ & $y=0.93+0.012 x-0.00002 x^{2}$ & $0.77 *$ & $y=0.00$ & $0.00 \mathrm{NS}$ \\
\hline SB & $y=12.29+0.044 x-0.00007 x^{2}$ & $0.51 * *$ & $y=50.10$ & $0.07^{\mathrm{NS}}$ \\
\hline CEC & $y=31.52+0.024 x$ & $0.61 * *$ & $y=80.44$ & $0.41^{\mathrm{NS}}$ \\
\hline BS & $y=45.22$ & $0.09^{\mathrm{NS}}$ & $y=62.17$ & $0.01^{\mathrm{NS}}$ \\
\hline
\end{tabular}

*** ${ }^{*}$ and ${ }^{\text {NS }}$-Significant at 1 and $5 \%$ probability and not significant, respectively. $\mathrm{OM}=$ organic matter; $\mathrm{CEC}=$ cation-exchange capacity; $\mathrm{SB}=$ sum of bases; $\mathrm{BS}$ = base saturation.

Table 6. Effect of treatments on macronutrient concentrations after maize cultivation in the Typic Quartzipsamment, and in the Rhodic Hapludox, depending on the application of potassium sources and rates.

\begin{tabular}{|c|c|c|c|c|c|c|c|c|c|c|}
\hline \multirow{2}{*}{ Treatments } & \multicolumn{5}{|c|}{ Typic Quartzipsamment } & \multicolumn{5}{|c|}{ Rhodic Hapludox } \\
\hline & $\mathbf{P}$ & $\mathbf{K}$ & $\mathrm{Ca}$ & Mg & $\mathrm{S}-\mathrm{SO}_{4}$ & $\mathbf{P}$ & $\mathbf{K}$ & $\mathrm{Ca}$ & Mg & $\mathrm{S}-\mathrm{SO}_{4}$ \\
\hline Source $(F)$ & $\mathrm{mg} \mathrm{dm}^{-3}$ & 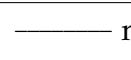 & $\mathrm{mol}_{\mathrm{c}} \mathrm{dm}$ & - & $\mathrm{mg} \mathrm{dm}^{-3}$ & $\mathrm{mg} \mathrm{dm}^{-3}$ & $-\mathrm{m}$ & $\mathrm{mol}_{\mathrm{c}} \mathrm{dm}$ & $\bar{z}$ & $\mathrm{mg} \mathrm{dm}^{-3}$ \\
\hline $\begin{array}{l}\text { Nepheline } \\
\text { syenite }\end{array}$ & 57.6 & $0.46 \mathrm{~b}$ & $11.2 \mathrm{a}$ & 5.6 & $51.5 \mathrm{a}$ & $54.0 \mathrm{~b}$ & $0.44 \mathrm{~b}$ & $31.5 \mathrm{ab}$ & 19.5 & $72.8 \mathrm{a}$ \\
\hline Phonolite & 55.7 & $0.44 \mathrm{~b}$ & $11.7 \mathrm{a}$ & 5.4 & $45.6 \mathrm{ab}$ & $66.8 \mathrm{a}$ & $0.40 \mathrm{c}$ & $32.5 \mathrm{a}$ & 20.0 & $67.2 \mathrm{a}$ \\
\hline $\mathrm{KCl}$ & 55.7 & $0.60 \mathrm{a}$ & $9.9 \mathrm{~b}$ & 5.4 & $35.5 \mathrm{~b}$ & $65.7 \mathrm{a}$ & $0.56 \mathrm{a}$ & $29.9 \mathrm{~b}$ & 19.6 & $52.7 \mathrm{~b}$ \\
\hline $\begin{array}{l}\text { F-test } \\
\text { K rates (DK) }\end{array}$ & $0.83^{\mathrm{NS}}$ & $28.19 * *$ & $11.93^{* *}$ & $0.42^{\mathrm{NS}}$ & $3.36 *$ & $18.88^{* *}$ & $133.06^{* *}$ & $4.49 *$ & $0.31^{\mathrm{NS}}$ & $14.94^{* *}$ \\
\hline $0\left(\mathrm{mg} \mathrm{kg}^{-1}\right)$ & 55.3 & 0.42 & 9.1 & 5.5 & 40.1 & 58.5 & 0.42 & 32.0 & 20.3 & 77.8 \\
\hline $50\left(\mathrm{mg} \mathrm{kg}^{-1}\right)$ & 56.0 & 0.47 & 10.0 & 5.1 & 39.3 & 63.5 & 0.42 & 31.2 & 18.9 & 66.0 \\
\hline $100\left(\mathrm{mg} \mathrm{kg}^{-1}\right)$ & 54.7 & 0.49 & 10.5 & 5.5 & 41.1 & 63.0 & 0.48 & 29.7 & 19.0 & 59.9 \\
\hline $150\left(\mathrm{mg} \mathrm{kg}^{-1}\right)$ & 53.8 & 0.45 & 11.8 & 5.2 & 41.5 & 62.5 & 0.44 & 31.5 & 19.7 & 62.5 \\
\hline $200\left(\mathrm{mg} \mathrm{kg}^{-1}\right)$ & 56.6 & 0.46 & 12.4 & 6.0 & 61.8 & 58.1 & 0.43 & 30.5 & 18.8 & 60.9 \\
\hline $400\left(\mathrm{mg} \mathrm{kg}^{-1}\right)$ & 61.5 & 0.70 & 11.7 & 5.5 & 43.3 & 67.4 & 0.61 & 32.3 & 21.5 & 58.5 \\
\hline F-test & 2.64 * & $17.71^{* *}$ & $10.14^{* *}$ & 1.01 NS & $1.69 \mathrm{NS}$ & $2.22 \mathrm{NS}$ & $50.04^{* *}$ & $1.52 \mathrm{NS}$ & $2.12 \mathrm{NS}$ & $3.53^{* *}$ \\
\hline $\begin{array}{l}F \text {-test }(\mathrm{F}) \times \\
(\mathrm{DK})\end{array}$ & $1.24^{\mathrm{NS}}$ & $13.14^{* *}$ & $3.94^{* *}$ & $3.92 * *$ & $2.22 *$ & $0.71^{\mathrm{NS}}$ & $67.37^{* *}$ & $1.64^{\mathrm{NS}}$ & $1.39 \mathrm{NS}$ & $2.12 *$ \\
\hline Overall average & 56.3 & 0.5 & 10.9 & 5.5 & 44.5 & 62.2 & 0.47 & 31.2 & 19.7 & 64.2 \\
\hline CV (\%) & 10.3 & 16.2 & 12.2 & 18.4 & 51.1 & 12.8 & 7.7 & 8.6 & 12.6 & 20.4 \\
\hline
\end{tabular}

**, * and NS_Significant at 1 and $5 \%$ probability and not significant, respectively. Averages followed by the same letter do not differ by Tukey's test at $5 \%$ probability. 
Regarding the comparison of $\mathrm{K}$ sources, $\mathrm{KCl}$ provided the highest $\mathrm{K}$ concentration in both soils (Table 6). Except for $\mathrm{Mg}$ concentration, there was an increasing linear adjustment for Ca concentration in the TQ, while a linear increase in $\mathrm{K}$ concentration in $\mathrm{RH}$ occurred with increasing rates of agromineral nepheline syenite (Table 7). The application of phonolite resulted in a linear increase in $\mathrm{P}$ concentration and a quadratic adjustment for TQ Ca and S concentrations at $\mathrm{K}$ rates of 278 and $225 \mathrm{mg} \mathrm{kg}^{-1}$, respectively, resulting in the highest concentrations of these elements. A linear decrease was observed in $\mathrm{S}$ concentration in $\mathrm{RH}$ soil. The concentration of $\mathrm{Ca}$ showed a quadratic adjustment with increasing rates of $\mathrm{KCl}$ in $\mathrm{TQ}$, with the highest concentrations obtained at a rate of $238 \mathrm{mg} \mathrm{kg}^{-1}$ of K. A linear increase in $\mathrm{K}$ concentrations was observed with increasing rates of $\mathrm{KCl}$.

Table 7. Macronutrient concentrations after maize cultivation in the Typic Quartzipsamment, and in the Rhodic Hapludox, depending on the rates and sources of $\mathrm{K}$.

\begin{tabular}{|c|c|c|c|c|c|c|c|c|c|c|}
\hline \multirow{2}{*}{ K Rates } & \multicolumn{5}{|c|}{ Typic Quartzipsamment } & \multicolumn{5}{|c|}{ Rhodic Hapludox } \\
\hline & $\mathbf{P}$ & K & $\mathrm{Ca}$ & Mg & $\mathrm{S}-\mathrm{SO}_{4}$ & $\mathbf{P}$ & K & $\mathrm{Ca}$ & Mg & $\mathrm{S}-\mathrm{SO}_{4}$ \\
\hline \multirow[b]{2}{*}{$\mathrm{mg} \mathrm{kg} \mathrm{kg}^{-1}$} & $\mathrm{mg} \mathrm{dm}^{-3}$ & \multirow{2}{*}{\multicolumn{3}{|c|}{ mmolc dm ${ }^{-3}$}} & $\mathrm{mg} \mathrm{dm}^{-3}$ & $\mathrm{mg} \mathrm{dm} \mathrm{m}^{-3}$ & \multicolumn{3}{|c|}{ mmolc dm ${ }^{-3}$} & $\mathrm{mg} \mathrm{dm}^{-3}$ \\
\hline & & & & & Nepheli & syenite & & & & \\
\hline 0 & 59.00 & 0.45 & 10.00 & 6.00 & 48.50 & 55.25 & 0.40 & 30.50 & 20.50 & 83.25 \\
\hline 50 & 59.50 & 0.55 & 10.25 & 5.75 & 39.75 & 55.50 & 0.40 & 32.00 & 18.50 & 64.25 \\
\hline 100 & 57.50 & 0.43 & 11.50 & 5.75 & 55.50 & 54.00 & 0.40 & 29.00 & 17.75 & 65.75 \\
\hline 150 & 55.75 & 0.45 & 11.25 & 5.50 & 48.25 & 53.75 & 0.45 & 34.00 & 20.75 & 76.25 \\
\hline 200 & 56.75 & 0.43 & 11.50 & 5.75 & 52.25 & 45.75 & 0.48 & 32.25 & 20.00 & 61.75 \\
\hline 400 & 57.25 & 0.48 & 13.00 & 5.25 & 44.75 & 60.00 & 0.48 & 31.25 & 19.50 & 85.75 \\
\hline \multirow[t]{2}{*}{ F-test } & $0.32 \mathrm{NS}$ & $0.08^{N S}$ & $11.63^{* *}$ & $1.02 \mathrm{NS}$ & $0.01 \mathrm{NS}$ & $0.35^{\mathrm{NS}}$ & $15.14^{* *}$ & $0.17^{\mathrm{NS}}$ & $0.03^{\mathrm{NS}}$ & $1.25^{\mathrm{NS}}$ \\
\hline & \multicolumn{10}{|c|}{ Phonolite } \\
\hline 0 & 51.50 & 0.43 & 9.25 & 5.50 & 22.50 & 63.75 & 0.40 & 32.75 & 19.75 & 84.50 \\
\hline 50 & 55.75 & 0.43 & 11.00 & 5.75 & 52.00 & 66.50 & 0.40 & 32.25 & 19.75 & 72.75 \\
\hline 100 & 52.50 & 0.43 & 11.00 & 5.75 & 43.00 & 68.50 & 0.40 & 31.75 & 20.25 & 68.75 \\
\hline 150 & 51.25 & 0.45 & 14.50 & 6.00 & 58.25 & 69.00 & 0.40 & 30.25 & 18.25 & 60.25 \\
\hline 200 & 57.00 & 0.43 & 12.00 & 4.75 & 57.25 & 64.75 & 0.40 & 32.25 & 20.00 & 67.25 \\
\hline 400 & 66.75 & 0.50 & 12.75 & 4.75 & 41.00 & 68.50 & 0.40 & 33.75 & 22.25 & 50.00 \\
\hline \multirow[t]{2}{*}{ F-test } & $15.32 * *$ & $11.84 * *$ & $10.49 * *$ & $2.66^{\mathrm{NS}}$ & $6.91 *$ & $0.33^{N S}$ & $0.00 \mathrm{NS}$ & $0.58^{\mathrm{NS}}$ & $2.41 \mathrm{NS}$ & $13.12 * *$ \\
\hline & \multicolumn{10}{|c|}{$\mathrm{KCl}$} \\
\hline 0 & 55.50 & 0.40 & 8.25 & 5.00 & 23.50 & 56.75 & 0.40 & 32.75 & 20.75 & 65.75 \\
\hline 50 & 53.00 & 0.45 & 9.00 & 4.00 & 26.25 & 68.75 & 0.40 & 29.50 & 18.50 & 61.00 \\
\hline 100 & 54.25 & 0.60 & 9.25 & 5.25 & 25.00 & 66.75 & 0.58 & 28.00 & 19.00 & 45.25 \\
\hline 150 & 54.50 & 0.50 & 9.75 & 4.25 & 18.25 & 64.75 & 0.48 & 30.25 & 20.25 & 51.00 \\
\hline 200 & 56.25 & 0.55 & 13.75 & 7.50 & 76.00 & 64.00 & 0.50 & 27.00 & 16.50 & 53.75 \\
\hline 400 & 60.75 & 1.13 & 9.50 & 6.75 & 44.25 & 73.75 & 1.05 & 32.00 & 22.75 & 39.75 \\
\hline F-test & $3.25 \mathrm{NS}$ & $181.43^{* *}$ & $18.97^{* *}$ & $16.30^{\mathrm{NS}}$ & $6.18^{\mathrm{NS}}$ & $5.29 *$ & $753.89 * *$ & $0.044^{\mathrm{NS}}$ & $2.32 \mathrm{NS}$ & $7.27^{* *}$ \\
\hline
\end{tabular}

The application of $\mathrm{KCl}$ resulted in an increase in $\mathrm{P}$ and $\mathrm{K}$ concentrations and a reduction in S concentration in RH soil (Table 8). The P and $\mathrm{K}$ concentrations in soils as a function of applied rates and sources were close and were being verified with $\mathrm{P}$ concentrations ranging from 45.8 to $73.8 \mathrm{mg} \mathrm{dm}^{-3}$ and $\mathrm{K}$ concentrations ranging from 0.4 to $1.1 \mathrm{mmol}_{\mathrm{C}} \mathrm{dm}^{-3}$ (Table 7). According to Raij et al. [33], these values are considered high for P (41 to $80 \mathrm{mg} \mathrm{dm}^{-3}$ ) and very low and low $\left(0.0\right.$ to $\left.1.5 \mathrm{mmol}_{\mathrm{c}} \mathrm{dm}^{-3}\right)$ for $\mathrm{K}$. The correction of soil acidity causes an increase in $\mathrm{OH}^{-}$ions from corrective material and may have desorption of phosphate ions, which increase their availability in soil [34]. The low $\mathrm{K}$ concentration with nepheline syenite application and phonolite are possibly related to the lower solubility of these sources and the duration of the experiment, which may directly affect the rapid release of this element in soil [10]. For $\mathrm{KCl}$, the results corroborate findings by Castro et al. [12] In that study, Brazilian rocks had low K concentrations in TQ. Santos [3] also reported that less soluble $\mathrm{K}$ sources lost less $\mathrm{K}$ when compared to $\mathrm{KCl}$ in sandy soil. 
Table 8. Coefficients of determination $\left(\mathrm{R}^{2}\right)$ and regression equations that best fit the relationships between macronutrient levels in soils after maize cultivation as a function of $\mathrm{K}$ sources.

\begin{tabular}{|c|c|c|c|c|}
\hline \multirow{2}{*}{ Variable (y) } & \multicolumn{2}{|c|}{ Typic Quartzipsamment } & \multicolumn{2}{|c|}{ Rhodic Hapludox } \\
\hline & Equation & $\mathbf{R}^{2}$ & Equation & $\mathbf{R}^{2}$ \\
\hline & \multicolumn{4}{|c|}{ Nepheline syenite } \\
\hline $\mathrm{P}$ & $y=57.62$ & $0.28 \mathrm{NS}$ & $\mathrm{y}=54.04$ & $0.05^{\mathrm{NS}}$ \\
\hline $\mathrm{K}$ & $y=0.46$ & $0.01 \mathrm{NS}$ & $y=0.47+0.0002 x$ & $0.74^{* *}$ \\
\hline $\mathrm{Ca}$ & $y=10.16+0.007 x$ & $0.91 * *$ & $y=31.58$ & $0.02^{\mathrm{NS}}$ \\
\hline $\mathrm{Mg}$ & $y=5.66$ & 0.79 NS & $y=19.50$ & $0.00 \mathrm{NS}$ \\
\hline \multirow[t]{2}{*}{$\mathrm{S}-\mathrm{SO} 4$} & $y=48.16$ & 0.00 NS & $y=72.83$ & $0.10^{\mathrm{NS}}$ \\
\hline & \multicolumn{3}{|c|}{ - Phonolite } & \\
\hline $\mathrm{P}$ & $y=50.37+0.036 x$ & $0.76^{* *}$ & $y=66.83$ & $0.21 \mathrm{NS}$ \\
\hline $\mathrm{K}$ & $y=0.44$ & $0.66^{\mathrm{NS}}$ & $y=0.40$ & $0.00 \mathrm{NS}$ \\
\hline $\mathrm{Ca}$ & $y=9.38+0.030 x-0.00005 x^{2}$ & $0.64^{* *}$ & $y=32.16$ & $0.15^{\mathrm{NS}}$ \\
\hline $\mathrm{Mg}$ & $y=5.41$ & $0.47^{\mathrm{NS}}$ & $y=20.04$ & $0.45^{\mathrm{NS}}$ \\
\hline S-SO4 & $y=27.88+0.281 x-0.0006 x^{2}$ & 0.75 * & $y=78.53-0.075 x$ & $0.83^{* *}$ \\
\hline $\mathrm{P}$ & $y=55.70$ & $0.75 \mathrm{NS}$ & $y=61.42+0.029 x$ & 0.53 * \\
\hline $\mathrm{K}$ & $y=0.34+0.001 x$ & $0.86^{* *}$ & $y=0.32+0.001 x$ & $0.83^{* *}$ \\
\hline $\mathrm{Ca}$ & $y=7.55+0.034 x-0.00007 x^{2}$ & $0.56^{* *}$ & $y=29.91$ & $0.00 \mathrm{NS}$ \\
\hline $\mathrm{Mg}$ & $y=5.45$ & 0.43 NS & $y=19.62$ & $0.15^{\mathrm{NS}}$ \\
\hline $\mathrm{S}-\mathrm{SO} 4$ & $y=35.54$ & 0.23 NS & $y=61.15-0.056 x$ & $0.67^{* *}$ \\
\hline
\end{tabular}

The concentrations of $\mathrm{Ca}^{2+}, \mathrm{Mg}^{2+}$ and $\mathrm{S}^{-\mathrm{SO}_{4}}{ }^{2-}$ after maize cultivation varied in both soils, ranging from 8.3 to $34.0 \mathrm{mmol}_{\mathrm{c}} \mathrm{dm}^{-3}, 4.0$ to $22.8 \mathrm{mmol}_{\mathrm{c}} \mathrm{dm}^{-3}$ and 18.3 to $85.8 \mathrm{mmol}_{\mathrm{C}} \mathrm{dm}^{-3}$ respectively, depending on applied $\mathrm{K}$ rates and sources (Table 7). These concentrations are considered high $\left(>7 \mathrm{mmol}_{\mathrm{c}} \mathrm{dm}^{-3}\right)$ for $\mathrm{Ca}^{2+}$, low $\left(<4.0 \mathrm{mmol}_{\mathrm{c}} \mathrm{dm}^{-3}\right)$ and high $\left(>8.0 \mathrm{mmol}_{\mathrm{c}} \mathrm{dm}^{-3}\right)$ for $\mathrm{Mg}^{2+}$ and high for $\mathrm{S}_{-} \mathrm{SO}_{4}{ }^{2-}\left(>10.0 \mathrm{mg} \mathrm{dm}^{-3}\right)$ [32]. The lowest concentrations of $\mathrm{Ca}^{2+}$ and $\mathrm{Mg}^{2+}$ were verified in TQ due to lower application of limestone, which significantly contributed to the differences of these elements in this soil.

Regarding the macronutrient concentrations in maize DM, there was an interaction found between $\mathrm{K}$ sources and rates for $\mathrm{N}, \mathrm{P}, \mathrm{K}$, and Mg concentrations in the TQ and for $\mathrm{K}$ and $\mathrm{Mg}$ concentrations in $\mathrm{RH}$ (Table 9). It was observed that macronutrient concentrations varied significantly according to the sources applied. Except for $\mathrm{K}$ concentrations, the other macronutrients were higher with application of nepheline syenite and phonolite when compared to $\mathrm{KCl}$. This fact must be related to the effect of the concentration of these elements on the plant tissue [35], since it is usual to find less plant growth in the soils that received less soluble sources.

Among the comparison of soil types, shoot $\mathrm{K}$ concentration in maize ranged from 3.86 to $8.50 \mathrm{~g} \mathrm{~kg}^{-1}$ in TQ and from 5.0 to $11.5 \mathrm{~g} \mathrm{~kg}^{-1}$ in RH (Table 9). The values observed in this study were similar to those obtained by Castro et al. [12] Regarding K sources (nepheline syenite and phonolite), the $\mathrm{K}$ concentration in plants did not differ from each other. Additionally, an increase in $\mathrm{K}$ rates promoted a linear decrease in shoot nutrient concentrations when maize plants were grown in both soils and an increase in shoot $\mathrm{K}$ concentration in maize plants grown in $\mathrm{RH}$ (Tables 10 and 11). The reductions in macronutrient concentrations must be related to the dilution effects [35] and inhibition, as described by Malavolta et al. [28]. 
Table 9. Effects of treatments on macronutrient concentrations in the shoot of maize plants grown in the Typic Quartzipsamment and in the Rhodic Hapludox, depending on the application of sources and rates of potassium.

\begin{tabular}{|c|c|c|c|c|c|c|c|c|c|c|c|c|}
\hline \multirow{2}{*}{ Treatments } & \multicolumn{6}{|c|}{ Typic Quartzipsamment } & \multicolumn{6}{|c|}{ Rhodic Hapludox } \\
\hline & $\mathbf{N}$ & $\mathbf{P}$ & $\mathbf{K}$ & $\mathrm{Ca}$ & $\mathrm{Mg}$ & S & $\mathbf{N}$ & $\mathbf{P}$ & K & $\mathrm{Ca}$ & $\mathrm{Mg}$ & S \\
\hline Source $(F)$ & & & & & & $\mathrm{g} \mathrm{kg}$ & & & & & & - \\
\hline Nepheline syenite & $16.0 \mathrm{a}$ & $4.4 \mathrm{a}$ & $3.93 \mathrm{~b}$ & $5.4 \mathrm{a}$ & $5.7 \mathrm{a}$ & $2.3 \mathrm{a}$ & $15.3 \mathrm{a}$ & $2.6 \mathrm{a}$ & $5.0 \mathrm{~b}$ & $5.4 \mathrm{a}$ & $6.0 \mathrm{a}$ & $1.8 \mathrm{a}$ \\
\hline Phonolite & $13.9 \mathrm{~b}$ & $4.4 \mathrm{a}$ & $3.86 \mathrm{~b}$ & $5.3 \mathrm{a}$ & $5.6 \mathrm{a}$ & $2.2 \mathrm{a}$ & $13.9 \mathrm{a}$ & $2.5 \mathrm{a}$ & $5.5 \mathrm{~b}$ & $5.6 \mathrm{a}$ & $6.0 \mathrm{a}$ & $1.7 \mathrm{a}$ \\
\hline $\mathrm{KCl}$ & $9.0 \mathrm{c}$ & $3.2 \mathrm{~b}$ & $8.50 \mathrm{a}$ & $4.3 \mathrm{~b}$ & $3.3 \mathrm{~b}$ & $1.6 \mathrm{~b}$ & $11.3 \mathrm{~b}$ & $2.0 \mathrm{~b}$ & $11.5 \mathrm{a}$ & $4.9 \mathrm{~b}$ & $4.9 \mathrm{~b}$ & $1.6 \mathrm{~b}$ \\
\hline F-test & $36.33^{* *}$ & $10.01^{* *}$ & $193.29^{* *}$ & $12.27^{* *}$ & $159.66^{* *}$ & $19.92^{* *}$ & $23.49^{* *}$ & $16.18^{* *}$ & $175.49^{* *}$ & $8.32 * *$ & $53.58^{* *}$ & $6.98^{* *}$ \\
\hline K rates (DK) & 236 & 69 & 4.11 & 67 & 50 & 28 & 168 & 31 & 47 & 56 & 60 & 19 \\
\hline $\begin{array}{l}0\left(\mathrm{mg} \mathrm{kg}^{-1}\right) \\
50\left(\mathrm{mg} \mathrm{kg}^{-1}\right)\end{array}$ & $\begin{array}{l}23.6 \\
15.3\end{array}$ & $\begin{array}{l}6.9 \\
5.1\end{array}$ & $\begin{array}{l}4.11 \\
4.35\end{array}$ & $\begin{array}{l}0.7 \\
5.6\end{array}$ & $\begin{array}{l}5.9 \\
5.3\end{array}$ & $\begin{array}{l}2.0 \\
2.3\end{array}$ & $\begin{array}{l}16.8 \\
13.6\end{array}$ & $\begin{array}{l}3.1 \\
2.4\end{array}$ & $\begin{array}{l}4.7 \\
5.6\end{array}$ & $\begin{array}{l}5.6 \\
5.4\end{array}$ & $\begin{array}{l}6.0 \\
6.0\end{array}$ & $\begin{array}{l}1.9 \\
1.7\end{array}$ \\
\hline $100\left(\mathrm{mg} \mathrm{kg}^{-1}\right)$ & 10.8 & 3.4 & 5.15 & 4.8 & 5.1 & 1.9 & 13.1 & 2.1 & 6.1 & 5.3 & 5.7 & 1.6 \\
\hline $150\left(\mathrm{mg} \mathrm{kg}^{-1}\right)$ & 11.5 & 3.2 & 5.58 & 4.5 & 4.7 & 1.8 & 11.5 & 2.1 & 6.7 & 4.9 & 5.4 & 1.6 \\
\hline $200\left(\mathrm{mg} \mathrm{kg}^{-1}\right)$ & 8.9 & 3.0 & 5.91 & 4.3 & 4.2 & 1.8 & 13.8 & 2.4 & 9.3 & 5.5 & 5.7 & 1.7 \\
\hline $400\left(\mathrm{mg} \mathrm{kg}^{-1}\right)$ & 7.9 & 2.6 & 7.47 & 4.0 & 4.0 & 1.7 & 12.0 & 2.0 & 11.7 & 4.9 & 5.0 & 1.6 \\
\hline F-test & $47.39 * *$ & $29.52 * *$ & 20.20 ** & $16.89 * *$ & $24.83 * *$ & $11.94 * *$ & $9.80 * *$ & $10.66^{* *}$ & $45.67 * *$ & $2.23^{\mathrm{NS}}$ & $9.31 * *$ & $3.12 *$ \\
\hline F-test $(\mathrm{F}) \times(\mathrm{DK})$ & $4.53^{* *}$ & $3.15^{* *}$ & $30.91 * *$ & $0.33^{\mathrm{NS}}$ & $7.58 * *$ & $1.07^{\mathrm{NS}}$ & $1.46^{\mathrm{NS}}$ & $0.88^{\mathrm{NS}}$ & $26.13 * *$ & $0.99 \mathrm{NS}$ & 8.56 ** & $1.31^{\mathrm{NS}}$ \\
\hline Overall average & 13.0 & 4.0 & 5.43 & 5.0 & 4.9 & 2.0 & 13.5 & 2.4 & 7.4 & 5.3 & 5.6 & 1.7 \\
\hline $\mathrm{CV}(\%)$ & 22.3 & 25.8 & 17.2 & 16.3 & 10.4 & 21.7 & 15.3 & 17.5 & 18.1 & 12.0 & 7.5 & 11.4 \\
\hline
\end{tabular}

**,* and NS_Significant at 1 and 5\% probability and not significant, respectively. Averages followed by the same letter do not differ by Tukey's test at $5 \%$ probability.

Table 10. Concentration of macronutrients in the shoots of maize plants grown in the Typic Quartzipsamment and in the Rhodic Hapludox, depending on the rates and sources of $\mathrm{K}$.

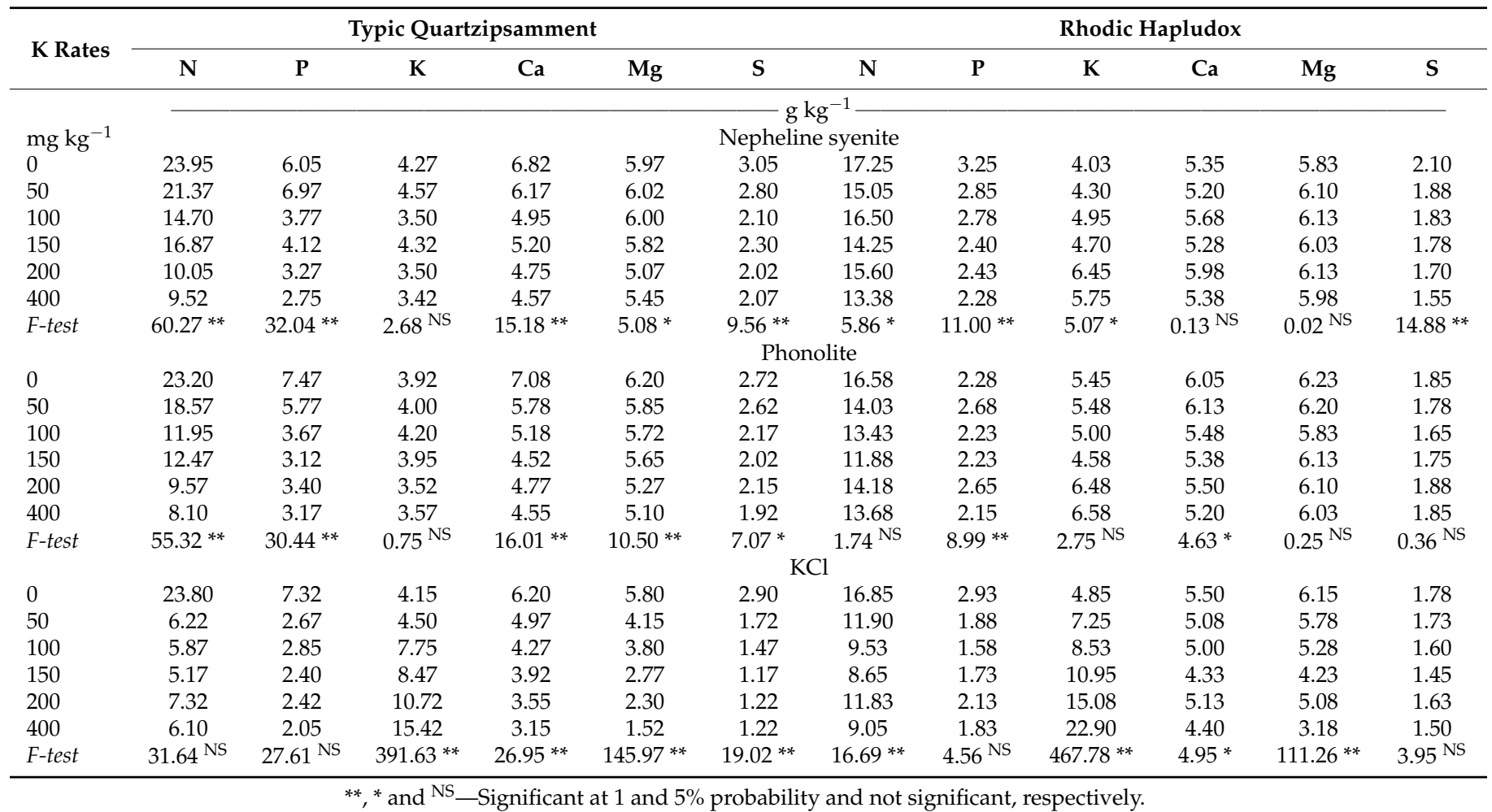

**, * and ${ }^{\mathrm{NS}}$-Significant at 1 and $5 \%$ probability and not significant, respectively. 
Table 11. Determination coefficients $\left(\mathrm{R}^{2}\right)$ and regression equations that best fit the relationships between the macronutrient concentration in the shoot of maize plants as a function of the K sources, in the different types of soil.

\begin{tabular}{|c|c|c|c|c|}
\hline \multirow{2}{*}{ Variable (y) } & \multicolumn{2}{|c|}{ Typic Quartzipsamment } & \multicolumn{2}{|c|}{ Rhodic Hapludox } \\
\hline & Equation & $\mathbf{R}^{2}$ & Equation & $\mathbf{R}^{2}$ \\
\hline & \multicolumn{4}{|c|}{ Nepheline syenite } \\
\hline $\mathrm{N}$ & $y=21.45-0.035 x$ & $0.74 * *$ & $y=16.52-0.008 x$ & $0.61 *$ \\
\hline $\mathrm{P}$ & $y=5.90-0.009 x$ & $0.64^{* *}$ & $y=2.99-0.002 x$ & $0.73^{* *}$ \\
\hline $\mathrm{K}$ & $y=3.93$ & $0.44 \mathrm{NS}$ & $y=4.31+0.004 x$ & 0.54 * \\
\hline $\mathrm{Ca}$ & $y=6.17-0.005 x$ & $0.64^{* *}$ & $y=5.47$ & $0.03^{\mathrm{NS}}$ \\
\hline $\mathrm{Mg}$ & $y=5.99-0.001 x$ & $0.45 *$ & $y=6.02$ & 0.01 NS \\
\hline \multirow[t]{2}{*}{$S^{\circ}$} & $y=2.72-0.002 x$ & $0.53^{* *}$ & $y=1.98-0.001 x$ & $0.86^{* *}$ \\
\hline & \multicolumn{3}{|c|}{ Phonolite } & \\
\hline $\mathrm{N}$ & $y=19.12-0.034 x$ & $0.70^{* *}$ & $y=13.95$ & $0.16^{\mathrm{NS}}$ \\
\hline $\mathrm{P}$ & $y=5.81-0.009 x$ & $0.52 * *$ & $y=2.83-0.002 x$ & $0.43^{* *}$ \\
\hline K & $y=3.86$ & $0.48^{\mathrm{NS}}$ & $y=5.59$ & $0.39^{N S}$ \\
\hline $\mathrm{Ca}$ & $y=6.09-0.005 x$ & $0.56^{* *}$ & $y=5.94-0.002 x$ & 0.67 * \\
\hline $\mathrm{Mg}$ & $y=6.02-0.002 x$ & $0.87^{* *}$ & $y=6.08$ & $0.10^{\mathrm{NS}}$ \\
\hline$S$ & $y=2.55-0.002 x$ & $0.68 *$ & $\mathrm{y}=1.79$ & $0.09^{\mathrm{NS}}$ \\
\hline $\mathrm{N}$ & \multicolumn{3}{|c|}{$-\mathrm{KCl}$} & $0.38^{\mathrm{NS}}$ \\
\hline $\mathrm{P}$ & $y=3.28$ & $0.38^{\mathrm{NS}}$ & $y=2.00$ & $0.17^{\mathrm{NS}}$ \\
\hline K & $y=4.10+0.029 x$ & $0.97^{* *}$ & $y=4.69+0.046 x$ & $0.98^{* *}$ \\
\hline $\mathrm{Ca}$ & $y=5.36-0.006 x$ & $0.75^{* *}$ & $y=5.24-0.002 x$ & 0.49 * \\
\hline $\mathrm{Mg}$ & $y=4.85-0.009 x$ & $0.82 * *$ & $y=6.02-0.007 x$ & $0.86^{* *}$ \\
\hline S & $y=2.09-0.003 x$ & $0.45^{* *}$ & $\mathrm{y}=1.61$ & $0.49^{\mathrm{NS}}$ \\
\hline
\end{tabular}

The K sources with low water solubility (nepheline syenite and phonolite) influenced shoot $\mathrm{K}$ accumulation in maize plants grown in both soils, with a linear increase in the accumulated amounts (Figure 1a,b). Increasing $\mathrm{KCl}$ ( $\mathrm{K}$ source with high water solubility) rates led to a linear increase in shoot $\mathrm{K}$ accumulation by maize plants in both soils, and it was noted that this source was responsible for significantly increasing the amount of $\mathrm{K}$ accumulated, characterizing luxury consumption by the crop. This fact is due to the greater availability of the nutrient in the soil, which is reflected in greater exports of the crop [10], even if it is not used in biomass production. For millet (Pennisetum glaucum), there have also been observations of an increase in $\mathrm{K}$ accumulation through the application of $\mathrm{KCl}$ and phonolite. However, there was no effect of nepheline syenite on the accumulation of $\mathrm{K}$ in this crop at the end of two 30-day cultivations [3].

There was positive interaction between sources and rates of $\mathrm{K}$ for plant height, shoot dry matter (SDM), stem diameter and leaf chlorophyll index (LCI) except for plant height in $\mathrm{RH}$ (Table 12). The application of $\mathrm{KCl}$ in both soils produced taller plants (135.2 in $\mathrm{RH}$ and $115.0 \mathrm{~cm}$ in TQ). The less soluble sources of $\mathrm{K}$ showed no differences in plant height in $\mathrm{RH}$ soil, while rates of $\mathrm{K}$ increased plant height in TQ (Table 12). The $\mathrm{K}$ rates applied via nepheline syenite led to a linear increase in plant height in both soils (Figures 2a and 3a). Conversely, there were quadratic adjustments in plant height when phonolite and $\mathrm{KCl}$ were used in both soils. The highest plant height values in TQ $(121.8$ and $145.6 \mathrm{~cm})$ were found through the rates of 329.1 and $289.4 \mathrm{mg} \mathrm{kg}^{-1}$, respectively (Figure 2c,e). Plant height in $\mathrm{RH}$ had a quadratic adjustment through the application of phonolite and $\mathrm{KCl}$, with application of estimated rates of 259.6 and $303.1 \mathrm{mg} \mathrm{kg}^{-1}$, respectively, promoting the highest values (phonolite $=128.5 \mathrm{~cm}$ and $\mathrm{KCl}=153.8 \mathrm{~cm}$ ) for this variable (Figure 3). 

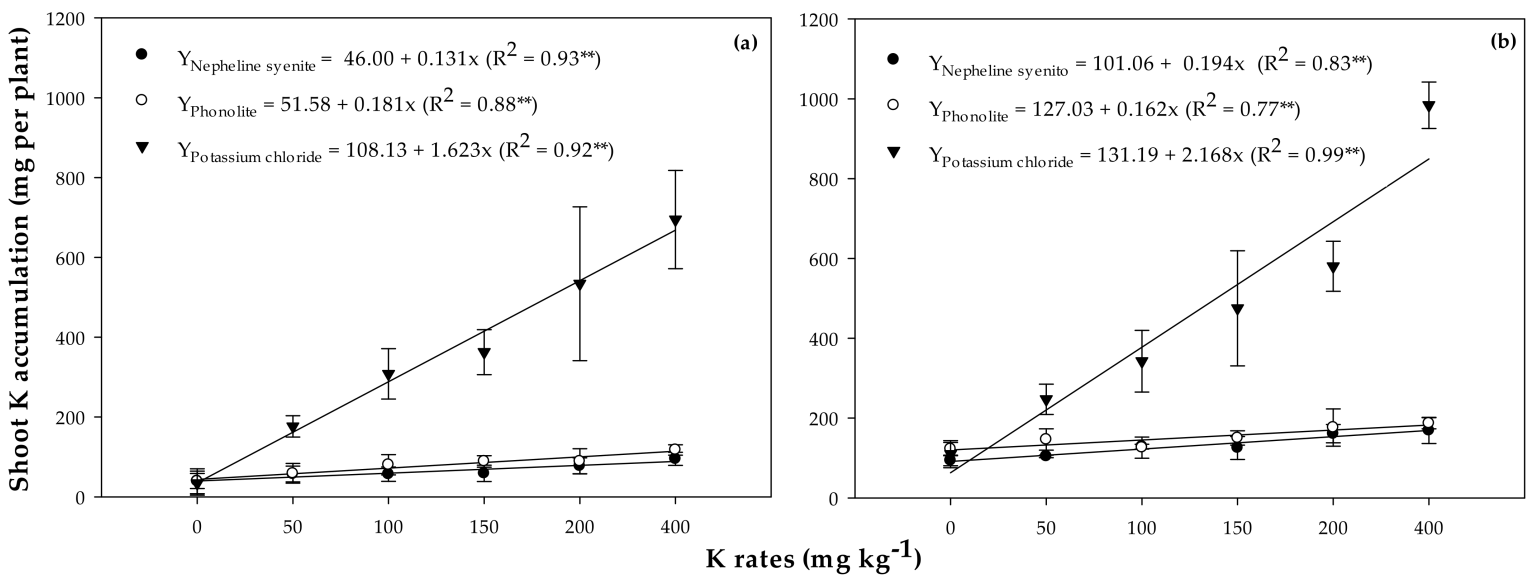

Figure 1. Shoot K accumulation of maize plants grown in the Typic Quartzipsamment (a) and in the Rhodic Hapludox (b), depending on the rates and sources of K. ${ }^{* *}$-Significant at the $p<0.01$ level. Bars represent the standard error of the mean.

Table 12. Effect of treatments on plant height, shoot dry matter, stem diameter, and leaf chlorophyll index (LCI), 45 days after the emergence of maize plants grown in the Typic Quartzipsamment (TQ) and in the Rhodic Hapludox (RH), depending on the application of $\mathrm{K}$ sources and rates.

\begin{tabular}{|c|c|c|c|c|c|c|c|c|}
\hline \multirow{2}{*}{ Treatments } & \multicolumn{2}{|c|}{ Plant Height } & \multicolumn{2}{|c|}{ Shoot Dry Matter } & \multicolumn{2}{|c|}{ Stem Diameter } & \multicolumn{2}{|c|}{ LCI } \\
\hline & TQ & RH & TQ & RH & TQ & RH & TQ & RH \\
\hline Source $(F)$ & \multicolumn{2}{|c|}{$\mathrm{cm}-$} & \multicolumn{2}{|c|}{ g per plant } & \multicolumn{2}{|c|}{$\mathrm{mm}$} & & \\
\hline Nepheline syenite & $87.7 \mathrm{c}$ & $119.3 \mathrm{~b}$ & $17.4 \mathrm{C}$ & $25.8 \mathrm{~b}$ & $9.8 \mathrm{~b}$ & $11.7 \mathrm{~b}$ & $27.4 \mathrm{a}$ & $38.2 \mathrm{ab}$ \\
\hline Phonolite & $95.3 \mathrm{~b}$ & $121.0 \mathrm{~b}$ & $20.7 b$ & $27.1 \mathrm{~b}$ & $10.4 \mathrm{~b}$ & $11.7 \mathrm{~b}$ & $26.6 \mathrm{a}$ & $39.2 \mathrm{ab}$ \\
\hline $\mathrm{KCl}$ & $115.0 \mathrm{a}$ & $135.2 \mathrm{a}$ & $37.1 \mathrm{a}$ & $37.0 \mathrm{a}$ & $12.7 \mathrm{a}$ & $14.2 \mathrm{a}$ & $20.4 \mathrm{~b}$ & $37.3 \mathrm{~b}$ \\
\hline F-test & $61.08^{* *}$ & $26.44^{* *}$ & $181.50 * *$ & $77.75 * *$ & $27.80 * *$ & $63.95 * *$ & $38.82 * *$ & $7.07^{* *}$ \\
\hline $\mathrm{K}$ rates $(\mathrm{DK})$ & & & & & & & & \\
\hline $0\left(\mathrm{mg} \mathrm{kg}^{-1}\right)$ & 67.4 & 110.1 & 9.3 & 23.0 & 8.2 & 11.65 & 30.0 & 38.6 \\
\hline $50\left(\mathrm{mg} \mathrm{kg}^{-1}\right)$ & 87.8 & 121.9 & 22.1 & 28.3 & 10.2 & 12.0 & 27.3 & 38.7 \\
\hline $100\left(\mathrm{mg} \mathrm{kg}^{-1}\right)$ & 99.6 & 125.5 & 25.0 & 30.4 & 10.5 & 12.5 & 23.8 & 38.6 \\
\hline $150\left(\mathrm{mg} \mathrm{kg}^{-1}\right)$ & 106.3 & 131.1 & 27.2 & 34.5 & 12.1 & 12.9 & 23.11 & 37.6 \\
\hline $200\left(\mathrm{mg} \mathrm{kg}^{-1}\right)$ & 114.5 & 128.5 & 31.6 & 30.3 & 12.0 & 12.8 & 22.5 & 36.9 \\
\hline $400\left(\mathrm{mg} \mathrm{kg}^{-1}\right)$ & 120.4 & 133.9 & 35.2 & 33.6 & 12.9 & 13.4 & 22.2 & 39.7 \\
\hline F-test & $57.77^{* *}$ & $12.35^{* *}$ & $66.43^{* *}$ & $17.73 * *$ & $17.02 * *$ & $6.48^{* *}$ & $12.92 * *$ & 2.43 * \\
\hline$F$-test $(\mathrm{F}) \times(\mathrm{DK})$ & $5.52 * *$ & 1.74 NS & $9.41^{* *}$ & $4.51 * *$ & 2.36 * & $3.31^{* *}$ & $2.37 *$ & 2.24 * \\
\hline Overall average & 99.3 & 125.2 & 25.1 & 30.0 & 11.0 & 12.5 & 24.8 & 38.3 \\
\hline $\mathrm{CV}(\%)$ & 8.8 & 6.6 & 15.2 & 11.3 & 12.9 & 7.1 & 12.2 & 5.5 \\
\hline
\end{tabular}

**,* and NS_Significant at 1 and $5 \%$ probability and not significant, respectively. Averages followed by the same letter do not differ by Tukey's test at $5 \%$ probability.
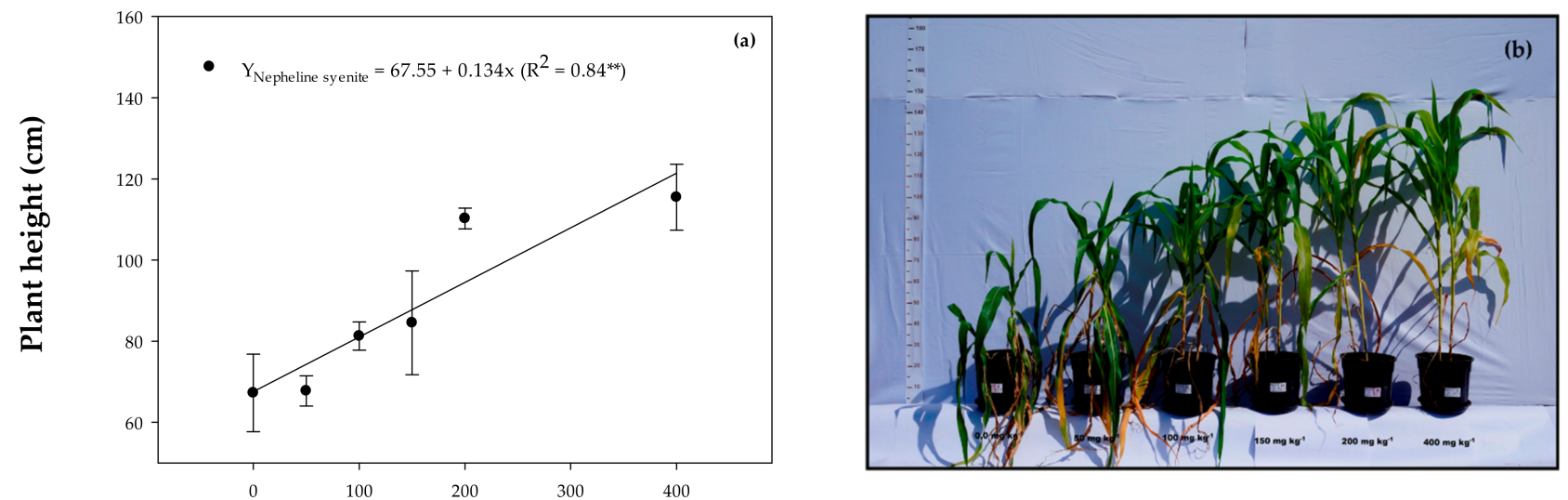

Figure 2. Cont. 

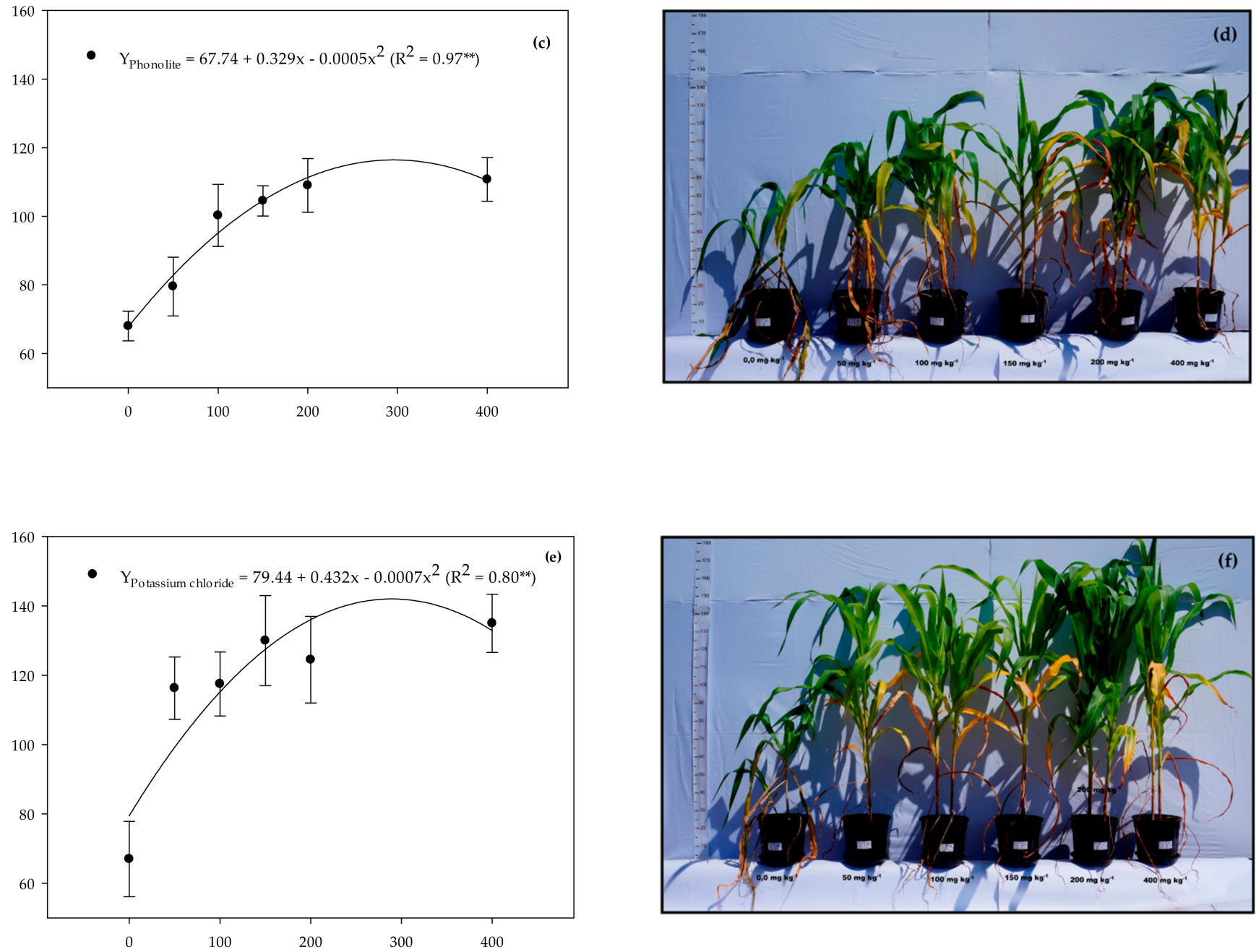

\section{$\mathrm{K}$ rates $\left(\mathrm{mg} \mathrm{kg}^{-1}\right)$}

Figure 2. Plant height and comparative growth 45 days after the emergence of maize grown in the Typic Quartzipsamment with increasing rates of $\mathrm{K}$ via nepheline syenite $(\mathbf{a}, \mathbf{b})$, phonolite $(\mathbf{c}, \mathbf{d})$, and potassium chloride $(\mathbf{e}, \mathbf{f}) .{ }^{*}$ - Significant at the $p<0.01$ level. Bars represent the standard error of the mean.
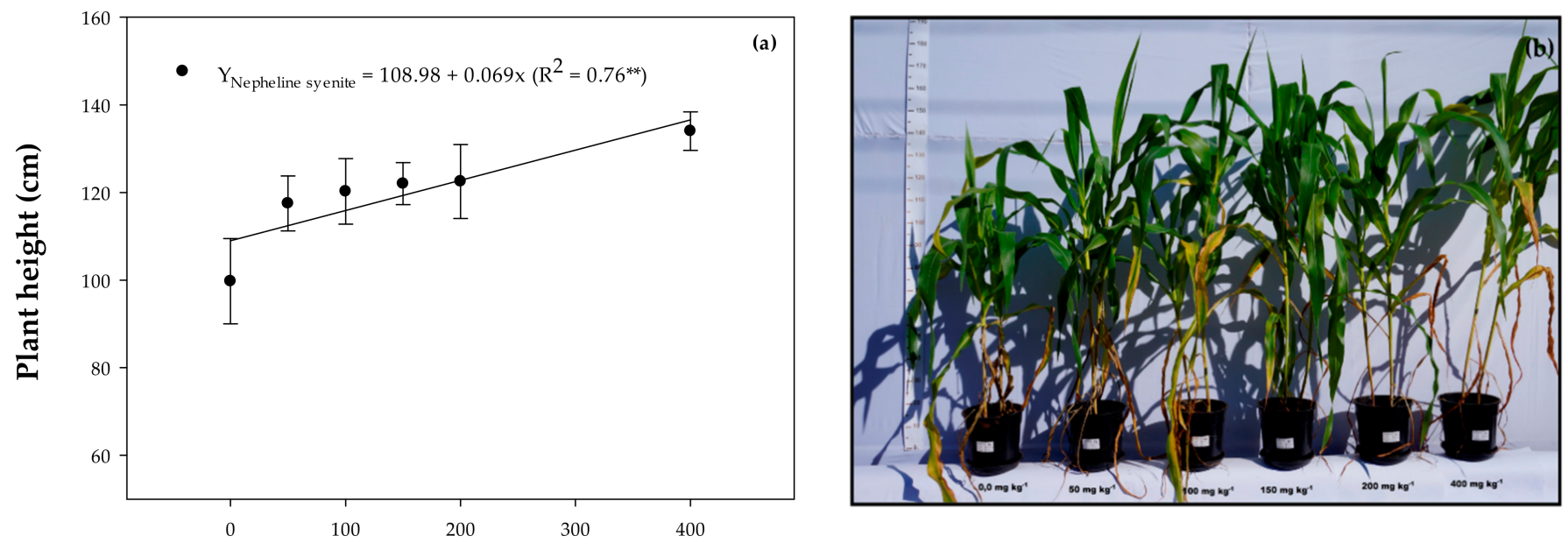

Figure 3. Cont. 

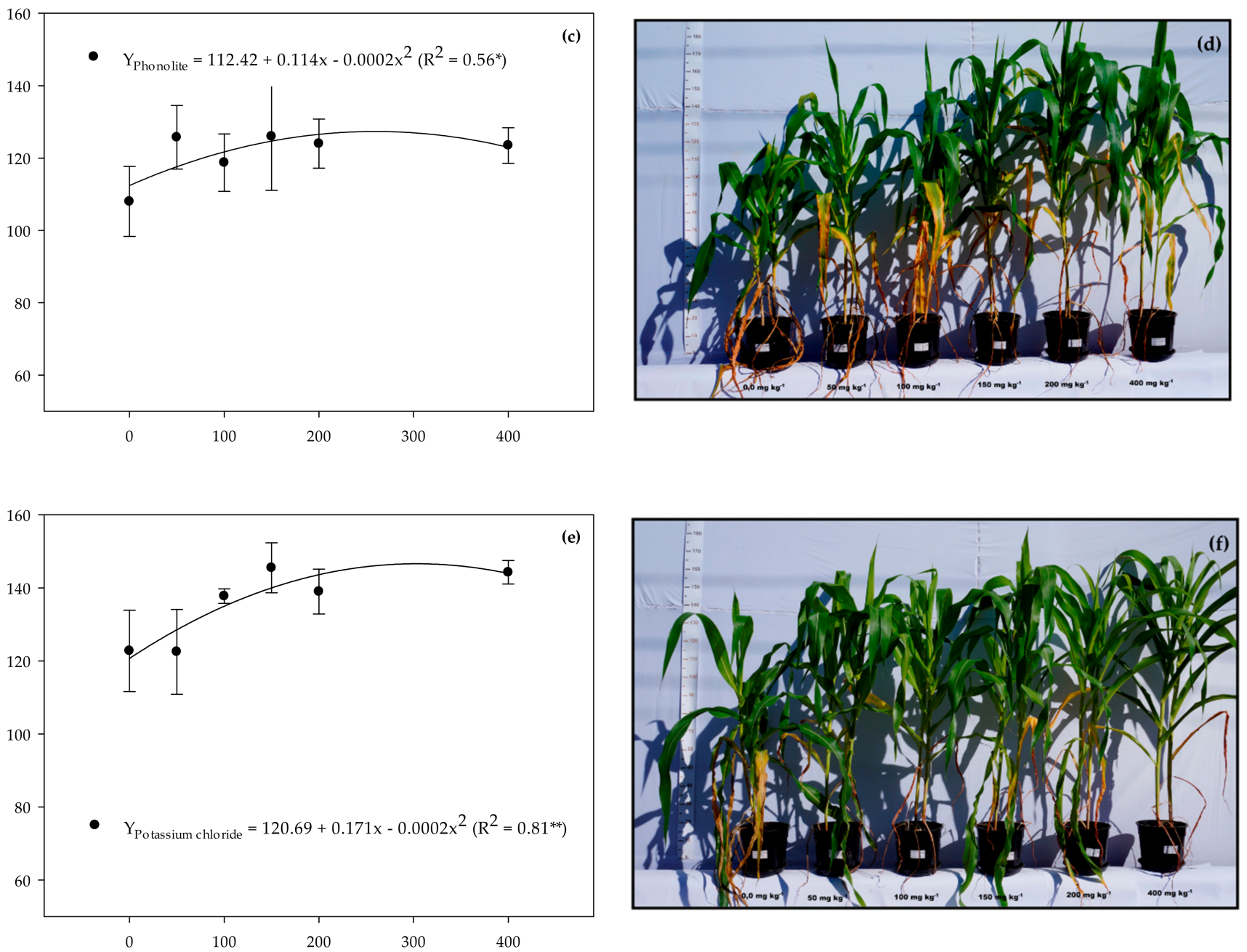

\section{K rates $\left(\mathrm{mg} \mathrm{kg}^{-1}\right)$}

Figure 3. Plant height and comparative growth 45 days after emergence of maize grown in the Rhodic Hapludox with increasing rates of $\mathrm{K}$ via nepheline syenite $(\mathbf{a}, \mathbf{b})$, phonolite $(\mathbf{c}, \mathbf{d})$, and potassium chloride $(\mathbf{e}, \mathbf{f}) .{ }^{*}$ - Significant at the $p<0.05$ level. **-Significant at the $p<0.01$ level. Bars represent the standard error of the mean.

Maize showed significant differences in plant growth (comparison must be intended among the plot of the same $\mathrm{K}$ source) and biomass production of shoot as a function of $\mathrm{K}$ applied soil rates. These reflect differences in SDM yield (Figures 2 and 3).

Regarding $\mathrm{K}$ sources, application of $\mathrm{KCl}$ provided greater SDM with no differences in both soils (Table 12). The rates of $\mathrm{K}$ from the sources of $\mathrm{KCl}$, nepheline syenite, and phonolite contributed to an increase in the production of SDM; however, no differences were found between nepheline syenite ( $25.8 \mathrm{~g}$ per plant) and phonolite ( $27.1 \mathrm{~g}$ per plant) in the production of SDM from plants grown in RH. However, plants grown on TQ soil that received phonolite (20.7 g per plant) resulted in greater SDM compared to nepheline syenite (17.4 g per plant) (Table 12). In evaluating the effect of the nepheline syenite and phonolite rates, it was found that SDM linearly increased (nepheline syenite: $y=10.59+0.045 x$; $p>0.01 ; \mathrm{R}^{2}=0.94$ and phonolite: $\left.\mathrm{y}=12.31+0.056 \mathrm{x} ; p>0.01 ; \mathrm{R}^{2}=0.94\right)$ in $\mathrm{TQ}$. We also verified that nepheline syenite rates provided a positive increment in SDM of the plant grown (nepheline syenite: $\mathrm{y}=24.00+0.012 \mathrm{x} ; p>0.05 ; \mathrm{R}^{2}=0.81$ ) in $\mathrm{RH}$ and a quadratic adjustment (phonolite: $\mathrm{y}=22.99+0.055 \mathrm{x}-0.0001 \mathrm{x}^{2} ; p>0.05 ; \mathrm{R}^{2}=0.57$ ) as a function of the phonolite rates applied in $\mathrm{RH}$ with an estimated $\mathrm{K}$ rate of $275.0 \mathrm{mg} \mathrm{kg}^{-1}$, providing the highest value ( $30.5 \mathrm{~g}$ per plant of SDM). The $\mathrm{K}$ rates in the form of $\mathrm{KCl}$ increased SDM production with application of an estimated optimal rates of $268.6 \mathrm{mg} \mathrm{kg}^{-1}$ in TQ 
$\left(\mathrm{KCl}: \mathrm{y}=16.0+0.274 \mathrm{x}-0.0002 \mathrm{x}^{2} ; p>0.01 ; \mathrm{R}^{2}=0.81\right)$ and $284.5 \mathrm{mg} \mathrm{kg}^{-1}$ in $\mathrm{RH}(\mathrm{KCl}:$ $\mathrm{y}=25.46+0.143 \mathrm{x}-0.0002 \mathrm{x}^{2} ; p>0.01 ; \mathrm{R}^{2}=0.81$ ).

In general, it was noted that SDM was higher in RH soil with application of $\mathrm{KCl}$. Our results are similar to those obtained by Castro et al. [12] for sunflower where differences may have been related to greater water and nutrient retention capacity of RH, thereby strengthening root volume and shoot growth. The stem diameter increased with $\mathrm{KCl}$ application in both soils, being $12.7 \mathrm{~mm}$ in TQ and $14.2 \mathrm{~mm}$ in the $\mathrm{RH}$. The application of nepheline syenite and phonolite provided similar values for stem diameter, ranging from 9.8 to $10.4 \mathrm{~mm}$ in TQ and $11.7 \mathrm{~mm}$ in RH. The $\mathrm{K}$ rates linearly increased (nepheline syenite: $\mathrm{y}=8.91+0.006 \mathrm{x} ; p>0.01 ; \mathrm{R}^{2}=0.76$ and phonolite: $\mathrm{y}=8.84+0.010 \mathrm{x} ; p>0.01 ; \mathrm{R}^{2}=0.86$ ) stem diameter in TQ soil and with no effect in RH soil. Conversely, there was a quadratic adjustment (KCl: $\left.\mathrm{y}=8.37+0.056 \mathrm{x}-0.0001 \mathrm{x}^{2} ; p>0.01 ; \mathrm{R}^{2}=0.99\right)$ as a function of the $\mathrm{KCl}$ rates applied in TQ with an estimated $\mathrm{K}$ rate of $276.4 \mathrm{mg} \mathrm{kg}^{-1}$, providing the highest value $(16.2 \mathrm{~mm})$ and a linear adjustment $\left(\mathrm{KCl}: \mathrm{y}=12.87+0.009 \mathrm{x} ; p>0.01 ; \mathrm{R}^{2}=0.75\right)$ for $\mathrm{RH}$. In relation to $\mathrm{LCI}$, higher values were observed with the application of less soluble sources (Table 12). There were similarities in the values obtained from $\mathrm{K}$ sources, which may be directly related to the higher $\mathrm{N}$ concentrations obtained in these plants (Table 12).

The agronomic efficiency index (AEI) of nepheline syenite and phonolite were lower than for $\mathrm{KCl}$ (Figure 4). The AEI varied from 10 to $50 \%$ with the increasing $\mathrm{K}$ rates of nepheline syenite and from 16 to $64 \%$ with application of phonolite in TQ soil (Figure 4a). In $\mathrm{RH}$, the AEI ranged from 7 to $27 \%$ and 18 to $44 \%$ with application of nepheline syenite and phonolite rates, respectively (Figure $4 \mathrm{~b}$ ). The AEI of nepheline syenite and phonolite were similar to those obtained by Santos [3] for millet with remineralizer application. These results indicated technical feasibility for the use of alternative K sources, mainly in the highest applied rates. In addition, these materials have a relatively slow dissolution when compared to conventional fertilizers, indicating a residual effect to maintain $\mathrm{K}$ availability, especially in low CEC soils. The fact that these materials do not promote a saline effect is another very favorable aspect for the use of these sources when compared to $\mathrm{KCl}$, not to mention the lesser external dependence they have on fertilizers.
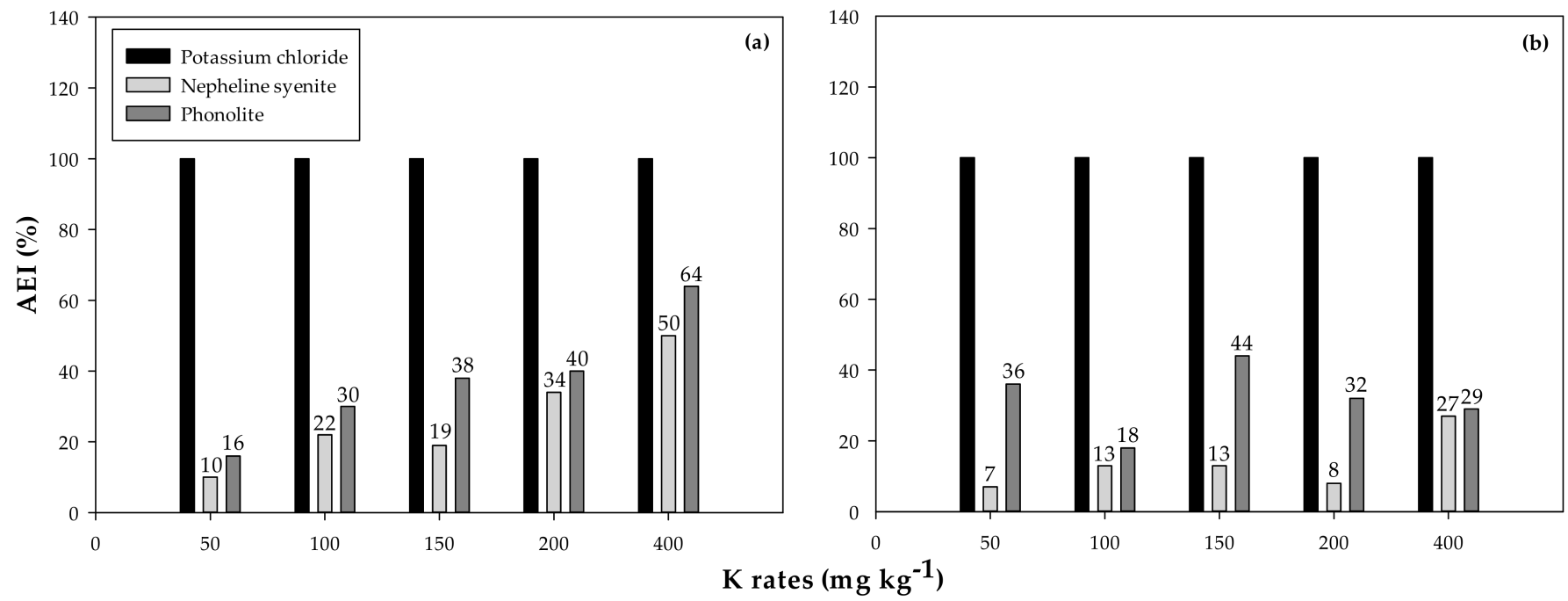

Figure 4. Agronomic efficiency index (AEI) of K sources tested in the Typic Quartzipsamment (a) and Rhodic Hapludox (b).

\section{Conclusions}

The application of $\mathrm{K}$ rates through nepheline syenite, phonolite and $\mathrm{KCl}$ sources did not influence soil $\mathrm{pH}$. The application of nepheline syenite and phonolite had a similar effect on soil chemical attributes (OM, pH, SB, CEC, and $\mathrm{BS}$ ) as well as on the concentrations of $\mathrm{K}, \mathrm{Ca}, \mathrm{Mg}$, and $\mathrm{S}$, in both soils. Conversely, these sources differed from $\mathrm{KCl}$ for soil $\mathrm{pH}, \mathrm{Al}, \mathrm{BS}, \mathrm{K}, \mathrm{Ca}$, and $\mathrm{S}$ in Typic Quartzipsamment and for $\mathrm{pH}, \mathrm{H}+\mathrm{Al}, \mathrm{BS}, \mathrm{K}, \mathrm{Ca}$, and 
$\mathrm{S}$ in Rhodic Hapludox. $\mathrm{KCl}$ provided higher $\mathrm{K}$ concentrations in both soils compared to nepheline syenite and phonolite. Macronutrient concentrations in maize shoots were similar for less soluble K sources (nepheline syenite and phonolite). The plants grown on the soil fertilized with $\mathrm{KCl}$ were shown to have higher $\mathrm{K}$ concentrations in both soils. All three $\mathrm{K}$ sources (nepheline syenite, phonolite, and $\mathrm{KCl}$ ) increased $\mathrm{K}$ accumulation in maize plants. However, we noted that $\mathrm{KCl}$ was responsible for a significant increase in $\mathrm{K}$ accumulation. Different rates of nepheline syenite, phonolite, and $\mathrm{KCl}$ did not influence leaf chlorophyll index, but plant height, stem diameter, and shoot dry matter increased in both soils. There was similar behavior between nepheline syenite and phonolite sources in relation to AEI. Nepheline syenite and phonolite sources reach $50 \%$ and $64 \%$ relative to $\mathrm{KCl} \mathrm{AEI}$, respectively, at the highest rates in sandy texture soil. Nepheline syenite and phonolite sources also reached $27 \%$ and $29 \%$ relative to $\mathrm{KCl}$ and AEI, respectively, at the highest rates in medium texture soil. These results indicate the efficiency of nepheline syenite and phonolite as alternative $\mathrm{K}$ sources for maize.

Author Contributions: Conceptualization, T.A.R.N., B.G.M., M.C.M.T.F., A.J., L.G.F.L., N.C.M. and A.M.; methodology, T.A.R.N., B.G.M., M.C.M.T.F., L.G.F.L., É.d.S.M., and A.J.; software, G.F.C. and B.G.M.; validation, É.d.S.M., N.C.M., A.D.J. and G.F.C.; formal analysis, T.A.R.N. and B.G.M.; investigation, T.A.R.N. and B.G.M.; resources, T.A.R.N.; data curation, T.A.R.N., B.G.M. and A.D.J;; writing—original draft preparation, T.A.R.N., B.G.M., A.J. and A.M.; writing-review and editing, T.A.R.N., C.H.A.-J., A.D.J., L.G.F.L., G.F.C.; É.d.S.M., and A.M.; visualization, M.C.M.T.F., L.G.F.L. and A.D.J.; supervision, T.A.R.N.; project administration, T.A.R.N.; funding acquisition, T.A.R.N. and N.C.M. All authors have read and agreed to the published version of the manuscript.

Funding: This research was financed by the Fundação de Ensino, Pesquisa e Extensão de Ilha Solteira, project No. 2.007/2018 (2018-2019). The research was co-financed by the Mineragro Pesquisa e Desenvolvimento LTDA. This study was financed in part by the Coordenação de Aperfeiçoamento de Pessoal de Nível Superior-Brasil (CAPES/AUXPE award number 88881.593505/2020-01).

Institutional Review Board Statement: Not applicable.

Informed Consent Statement: Not applicable.

Data Availability Statement: All data generated or analyzed during this study are included in this published article.

Acknowledgments: The GENAFERT (Grupo de Estudo em Nutrição, Adubação e Fertilidade do Solo) for technical support. The Coordenação de Aperfeiçoamento de Pessoal de Nível SuperiorBrasil (CAPES) for the master's scholarship granted to the second author. The World Academy of Sciences (TWAS) and the National Council for Scientific and Technological Development (CNPq) for the third author's scholarship (CNPq/TWAS grant \# 166331/2018-0). The CNPq for the Research Grant to the seventh author (grant \# 312728/2017-4).

Conflicts of Interest: The authors declare no conflict of interest. The funders had no role in the design of the study, the collection, analyses or interpretation of data, the writing of the manuscript or the decision to publish the results.

\section{References}

1. Malavolta, E. Mineral Plant Nutrition Manual, 1st ed.; Agronômica Ceres: São Paulo, Brazil, 2006; p. 638.

2. Nascimento, C.O. Evaluation of Biodegradable Polymer Coatings in KCl Granules Obtained through Fluidized Bed. Master's Thesis, Federal University of Bahia, Salvador, Brazil, 2014.

3. Santos, D.S. Rochagem as an Alternative to Supply Potassium to Crops. Master's Thesis, Federal University of Uberlândia, Uberlândia, Brazil, 2013.

4. AMA BRASIL. Brazilian Fertilizer Mixers Association. Production and Import of Fertilizers. Available online: http://amabrasil.agr. br/web/portfolio-item/producao-e-importacao-de-fertilizantes/ (accessed on 3 June 2020).

5. Di Loreto y Sampaio, M.; Melo, T.R.; Moreira, A. Potassium and spontaneous clay dispersion in two soils of Paraná State. Agrotrópica 2019, 31, 205-212.

6. Cantarella, H. Fertilization with nitrogen, potassium and sulfur. In Fertilization and Liming Recommendations for the State of São Paulo, 2nd ed.; van Raij, B., Cantarella, H., Quaggio, J.A., Furlani, A.M.C., Eds.; Campinas Agronomic Institute: Campinas, Brazil, 1997; Volume 1, pp. 22-27. 
7. Sangoi, L.; Ernani, P.R.; Bianchet, P.; Vargas, V.P.; Picoli, G.J. Effect of rates of potassium chloride on the germination and initial growth of maize, in soils with contrasting textures. Rev. Bras. Milho Sorgo 2009, 8, 187-197. [CrossRef]

8. National Fertilizer Diffusion Association-ANDA. Macro Indicators. Available online: http://www.anda.org.br/estatisticas/ (accessed on 24 May 2019).

9. Ministry of Industry, Foreign Trade and Services (MDIC). Comex Vis: Visualizations of Foreign Trade. Available online: http:/ / www.mdic.gov.br/comercio-exterior/estatisticas-de-comercio-exterior/comex-vis/frame-ppi (accessed on 25 May 2020).

10. Resende, A.V.; Martins, E.S.; Olivera, C.G.; Sena, M.C.; Machado, C.T.T.; Kimpara, J.D.; Oliveira Filho, E.C. Supply of potassium and research on the use of "in natura" rocks in Brazilian agriculture. Espaç. Geogr. 2006, 9, $19-42$.

11. Almeida, G.R. Petrographic analysis, geophysical and geobotanical prospecting: Agroecological potential in the central portion of the state of Tocantins. In Congresso Brasileiro de Rochagem, Proceedings of the III Brazilian Congress of Rochagem, Pelotas, Brazil, 8-11 November 2016; Bamberg, A.L., Silveira, C.A.P., Martins, E.S., Bergmann, M., Martinazzo, R., Theodoro, S.H., Eds.; Triunfal Gráfica e Editora: Assis, Brazil, 2017; Volume 3, pp. 129-133.

12. Castro, C.; Oliveira, F.A.; Moreira, A.; Salinet, L.H.; Veronesi, C.O. Brazilian rocks as an alternative source of potassium for sunflower cultivation. Espaç. Geogr. 2006, 9, 179-193.

13. Melamed, R.; Gaspar, J.C.; Miekeley, N. Rock powder as alternative fertilizers for sustainable production systems in tropical soils. In Fertilizers: Agribusiness and Sustainability, 1st ed.; Loureiro, F.E.L., Melamed, R., Figueiredo Neto, J., Eds.; CETEM/MCT: Rio de Janeiro, Brazil, 2009; Volume 1, pp. 385-395.

14. Moreira, A.; Castro, C.; Oliveira, F.A.; Salinet, L.H.; Sfredo, G.J. Residual effect of Brazilian rocks as soil acidity fertilizers and correctives. Espaç. Geogr. 2006, 9, 163-177.

15. Cola, G.P.A.; Simão, J.B.P. Rochagem as an alternative form of potassium supplementation in agroecological agriculture. Rev. Verde Agroecol. Desenvolv. Sustent. 2012, 7, 1-8. Available online: https://dialnet.unirioja.es/descarga/articulo/7422237.pdf (accessed on 25 May 2020).

16. Alvarez, V.H.; Novais, R.F.; Barros, N.F.; Cantarutti, R.B.; Lopes, A.S. Interpretation of the results of soil analysis. In Recommendations for the Use of Correctives and Fertilizers in Minas Gerais, 5th ed.; Ribeiro, A.C., Guimarães, P.T.G., Alvarez, V.H., Eds.; UFV: Viçosa, Brazil, 1999; Volume 1, pp. 25-32.

17. Moreira, A.; Fageria, N.K.; Souza, G.B.; Freitas, A.R. Production, nutritional status and chemical properties of soils with addition of cattle manure, reactive natural phosphate and biotite schist in Massai cultivar. Rev. Bras. Zootec. 2010, 39, 1883-1888. [CrossRef]

18. Faquin, V. Effect of the Heat Treatment of Nepheline Syenite Added with Dolomitic Limestone, on the Availability of Potassium to Maize (Zea mays L.), in a Greenhouse. Master's Thesis, School of Agriculture “Luiz de Queiroz", Piracicaba, Brazil, 1982.

19. Siqueira, J.O.; Guedes, G.A.A.; Ribeiro, M.A.V. Potassium availability of the Poços de Caldas nepheline syenite, evaluated in successive crops with maize. Pesq. Agropec. Bras. 1985, 20, 299-307.

20. Martins, C.C. Potassium: Alternative Sources, Heat Treatments and Availability for Maize Plants (Zea mays L.). Master's Thesis, Center for Agricultural Sciences-Federal University of Espírito Santos, Espírito Santo, Brazil, 2014.

21. Alovisi, A.M.T.; Alovisi, A.A.; Hartmann, C.F.; Tokura, L.K.; Silva, R.S. Attributes of soil fertility and productivity of maize and soybeans influenced by rock formation. Acta Iguazu 2017, 6, 55-68.

22. Coelho, A.M.; França, G.E. Be the Doctor of Your Maize, 2nd ed.; Potafos: Piracicaba, Brazil, 1995; pp. 1-9.

23. USDA. Soil Survey Staff. Keys to Soil Taxonomy, 12th ed.; Natural Resources Conservation Service: Washington, DC, USA, 2014. Available online: https://www.nrcs.usda.gov/wps/portal/nrcs/detail/soils/survey/class/taxonomy/?cid=nrcs142p2_053580 (accessed on 21 October 2020).

24. van Raij, B.; Cantarella, H. Maize. Fertilization and Liming Recommendations for the State of São Paulo, 2nd ed.; van Raij, B., Cantarella, H., Quaggio, J.A., Furlani, A.M.C., Eds.; Campinas Agronomic Institute: Campinas, Brazil, 1997; Volume 1, pp. 56-59.

25. Malavolta, E. Elements of Mineral Nutrition of Plants, 1st ed.; Editora Agronômica Ceres: São Paulo, Brazil, $1980 ;$ p. 251.

26. van Raij, B.; Andrande, J.C.; Cantarella, H.; Quaggio, J.A. Chemical Analysis to Assess Fertility in Tropical Soils, 1st ed.; Campinas Agronomic Institute: Campinas, Brazil, 2001; p. 285.

27. Teixeira, P.C.; Donagemma, G.K.; Fontana, A.; Teixeira, W.G. Manual de Métodos de Análise de Solo, 3rd ed.; Embrapa Informação Tecnológica: Brasília, Brazil, 2017; p. 573.

28. Malavolta, E.; Vitti, G.C.; Oliveira, S.A. Evaluation of the Nutritional Status of Plants: Principles and Applications, 2nd ed.; Potafos: Piracicaba, Brazil, 1997; p. 319.

29. Goedert, W.; Souza, D.M.G.; Rein, T.A. Methodological Principles for Agronomic Evaluation of Phosphorus Sources, 1st ed.; Embrapa: Planaltina, Brazil, 1986; p. 23.

30. R Core Team. R: A Language and Environment for Statistical Computing; R Foundation for Statistical Computing: Vienna, Austria, 2013; Available online: http:/ / www.r-project.org/index.html (accessed on 18 May 2020).

31. Raij, B. Soil Fertility and Nutrient Management, 1st ed.; International Plant Nutrition Institute (IPNI): Piracicaba, Brazil, $2011 ;$ p. 420.

32. Echart, C.L.; Cavalli-Molina, S. Phytotoxicity of aluminum: Effects, tolerance mechanism and its genetic control. Cienc. Rural 2001, 31, 531-541. [CrossRef]

33. van Raij, B.; Cantarella, H.; Quaggio, J.A.; Furlani, A.M.C. (Eds.) 4. Interpretation of soil analysis results. In Fertilization and Liming Recommendations for the State of São Paulo, 2nd ed.; Campinas Agronomic Institute: Campinas, Brazil, 1997; Volume 1, pp. 8-13. 
34. Sato, S.; Comerford, N.B. Influence of soil pH on inorganic phosphorus sorption and desorption in a humid Brazilian Ultisol. Rev. Bras. Ciência Solo 2005, 29, 685-694. [CrossRef]

35. Fia, R.; Matos, A.T.; Aguirre, C.I. Productivity and concentration of nutrients and heavy metals in maize fertilized with increasing rates of chilled sewage sludge. Eng. Agríc. 2006, 14, 39-50. 